\title{
Cochrane
}

Cochrane Database of Systematic Reviews

\section{Taxation of sugar-sweetened beverages for reducing their consumption and preventing obesity or other adverse health outcomes (Protocol)}

Heise TL, Katikireddi SV, Pega F, Gartlehner G, Fenton C, Griebler U, Sommer I, Pfinder M, Lhachimi SK

Heise TL, Katikireddi SV, Pega F, Gartlehner G, Fenton C, Griebler U, Sommer I, Pfinder M, Lhachimi SK.

Taxation of sugar-sweetened beverages for reducing their consumption and preventing obesity or other adverse health outcomes. Cochrane Database of Systematic Reviews 2016, Issue 8. Art. No.: CD012319.

DOI: 10.1002/14651858.CD012319.

www.cochranelibrary.com

Taxation of sugar-sweetened beverages for reducing their consumption and preventing obesity or other adverse health outcomes (Protocol)

Copyright $\odot 2016$ The Cochrane Collaboration. Published by John Wiley \& Sons, Ltd. 
TABLE OF CONTENTS

HEADER . . . . . . . . . . . . . . . . . . . . . . . . . . . . . . . . . . . . . . . 1

ABSTRACT . . . . . . . . . . . . . . . . . . . . . . . . . . . . . . . . . . . . . . 1

BACKGROUND . . . . . . . . . . . . . . . . . . . . . . . . . . . . . . . . . . . . . . . . . . . . . .

Figure 1. . . . . . . . . . . . . . . . . . . . . . . . . . . . . . . . . . . . . . 5

OBJECTIVES . . . . . . . . . . . . . . . . . . . . . . . . . . . . . . . . . . . . . . . . . . . .

METHODS . . . . . . . . . . . . . . . . . . . . . . . . . . . . . . . . . . . . . . . . . . . . . . .

ACKNOWLEDGEMENTS . . . . . . . . . . . . . . . . . . . . . . . . . . . . . . . . . 13

REFERENCES . . . . . . . . . . . . . . . . . . . . . . . . . . . . . . . . . . . . . 13

ADDITIONAL TABLES . . . . . . . . . . . . . . . . . . . . . . . . . . . . . . . . . . . . . . . . . . . .

APPENDICES . . . . . . . . . . . . . . . . . . . . . . . . . . . . . . . . . . . . . 31

CONTRIBUTIONS OF AUTHORS . . . . . . . . . . . . . . . . . . . . . . . . . . . . . . . . . . . . . . .

DECLARATIONS OF INTEREST . . . . . . . . . . . . . . . . . . . . . . . . . . . . . . . . . . . . . . . .

SOURCES OF SUPPORT . . . . . . . . . . . . . . . . . . . . . . . . . . . . . . . . . . . . . . . . . . . .

Taxation of sugar-sweetened beverages for reducing their consumption and preventing obesity or other adverse health outcomes 


\title{
Taxation of sugar-sweetened beverages for reducing their consumption and preventing obesity or other adverse health outcomes
}

\author{
Thomas L Heise ${ }^{1,2}$, Srinivasa V Katikireddi ${ }^{3}$, Frank Pega ${ }^{4}$, Gerald Gartlehner ${ }^{5}$, Candida Fenton ${ }^{3}$, Ursula Griebler ${ }^{6}$, Isolde Sommer ${ }^{6}$, \\ Manuela Pfinder ${ }^{1,2,7}$, Stefan K Lhachimi ${ }^{1,2}$ \\ ${ }^{1}$ Institute for Public Health and Nursing Research, Health Sciences Bremen, University of Bremen, Bremen, Germany. ${ }^{2}$ Research \\ Group for Evidence-Based Public Health, Leibniz Institute for Prevention Research and Epidemiology, Bremen, Germany. ${ }^{3} \mathrm{MRC} / \mathrm{CSO}$ \\ Social and Public Health Sciences Unit, University of Glasgow, Glasgow, UK. ${ }^{4}$ Public Health, University of Otago, Wellington, New \\ Zealand. ${ }^{5}$ Cochrane Austria, Danube University Krems, Krems, Austria. ${ }^{6}$ Department for Evidence-based Medicine and Clinical \\ Epidemiology, Danube University Krems, Krems, Austria. ${ }^{7}$ Department of Health Promotion/Occupational Health Management, \\ AOK Baden-Württemberg, Stuttgart, Germany
}

Contact address: Thomas L Heise, Institute for Public Health and Nursing Research, Health Sciences Bremen, University of Bremen, Bibliothekstr. 1, Bremen, 28359, Germany. heise@leibniz-bips.de.

Editorial group: Cochrane Public Health Group.

Publication status and date: New, published in Issue 8, 2016.

Citation: Heise TL, Katikireddi SV, Pega F, Gartlehner G, Fenton C, Griebler U, Sommer I, Pfinder M, Lhachimi SK. Taxation of sugar-sweetened beverages for reducing their consumption and preventing obesity or other adverse health outcomes. Cochrane Database of Systematic Reviews 2016, Issue 8. Art. No.: CD012319. DOI: 10.1002/14651858.CD012319.

Copyright (C) 2016 The Cochrane Collaboration. Published by John Wiley \& Sons, Ltd.

\section{A B S T R A C T}

This is the protocol for a review and there is no abstract. The objectives are as follows:

To assess the effects of taxation of sugar-sweetened beverages (SSBs) on SSB consumption, energy intake, overweight, obesity, and other adverse health outcomes in the general population.

\section{B A C K G R O U N D}

\section{Description of the condition}

\section{Obesity}

Overweight and obesity refer to adverse medical conditions of "abnormal or excessive body fat accumulations in adipose tissue" (WHO 2000; WHO 2011). The increase in prevalence of over- weight and obesity among children and adults is one of the leading contemporary global public health issues, and puts overweight and obesity prevention on local, national and international policy agendas. Limiting the intake of 'free sugars' (monosaccharides and disaccharides added to foods) or other added sugars from sources such as sugar-sweetened beverage (SSB) products through price and tax-based measures could be one important means of reducing this burden, as well as achieving other public health goals (Chan 2010; NICE 2012; WHO 2013). Such interventions may increasingly be warranted in many countries, given that the combined global prevalence of overweight and obesity has substantially in- 
creased over the last decades in low-, middle-, and high-income countries (1980 to $2013:+27.5 \%$ adults; $+47.1 \%$ children $)(\mathrm{Ng}$ 2014). According to data for 2014 from the latest WHO reports, $39 \%$ (40\% female; $38 \%$ male) of the worldwide adult population is overweight, defined as a body mass index (BMI) $\geq 25$ $\mathrm{kg} / \mathrm{m}^{2}$. Furthermore, $15 \%$ of females and $11 \%$ of males of the global adult population are obese, defined as a BMI $\geq 30 \mathrm{~kg} /$ $\mathrm{m}^{2}$. However, there are considerable between-country inequalities in the prevalence of obesity. Countries of the Pacific Islands are among those with the highest obesity prevalence globally. For example, in some of these countries more than half of all females are obese. In the USA, over one third of the general adult population is obese, whereas other populous countries like India and China currently have a relatively low obesity prevalence of less than $10 \%$. In 2010, overweight and obesity accounted for an estimated 93.6 million disability-adjusted life years (DALYs) and 3.4 million deaths worldwide (WHO 2014).

\section{Health conditions associated with obesity}

Human metabolism, dietary intake and physical activity - all of which are influenced by social, economic, and built environments as well as genetic traits - play a vital and interrelated role in the aetiology of overweight and obesity. Furthermore, behavioural, environmental, economic and cultural factors can affect dietary intake and the level of physical activity (Goni 2015; MacLean 2015; Qi 2012; Weinsier 1998). The major physiological cause of overweight and obesity is an imbalanced energy intake resulting from a combination of the overconsumption of energy-dense foods, such as SSBs, disproportionate to the energy expended (e.g. due to lack of exercise or other physical activity) (Hall 2011; Hill 2006). The early onset of an abnormal share of body fat accumulation in childhood can adversely impact upon an individual's health in adulthood and predispose them to lifelong obesity (Juonala 2011). In general, overweight and obesity are considered to be major risk factors for several leading non-communicable diseases such as cardiovascular diseases (CVDs), type 2 diabetes, various cancers and osteoarthritis (Guh 2009). Overweight and obesity are also associated with severe psychiatric disorders (Simon 2006). In addition, in some countries, overweight and obesity may also contribute to loss of social capital as obese people are often socially stigmatised, and thus may lead to social exclusion (Puhl 2009). However, in other countries such as some Pacific Islands countries, overweight and obesity can be signifiers of high social status, and may thus be seen as socially desirable (Mavoa 2008).

\section{Social inequality and economic burden of obesity}

There are both between-country and within-country inequalities in overweight and obesity. With regard to between-country inequalities, morbidity and mortality rates associated with overweight and obesity are generally higher in middle- and high-income countries than in low-income countries (WHO 2009). With regards to within-country inequalities, the prevalence of overweight and obesity is highly influenced by aspects relevant to health disparities and the social determinants of health. These include both individual (e.g. socio-economic status (SES), age, gender, ethnicity, education, occupation) and contextual factors (e.g. food security, built environment including housing) (Drewnowski 2004; Ng 2014; Robroek 2013; Salois 2012; Valera 2015). Evidence from a recent review of studies in low-income countries shows a positive association between SES and obesity: obesity is more prevalent in higher SES groups (Dinsa 2012). In contrast, in middle- and high-income countries the relationship between SES and obesity is mixed or negatively associated: obesity is more prevalent in lower SES groups (Dinsa 2012; McLaren 2007; Ogden 2010; Wang 2012).

In economic terms, overweight and obesity have a serious impact on public health systems via direct (e.g. treatment costs) and indirect (e.g. reduced work productivity) costs (Van Nuys 2014). A recent review - with a majority of studies from high-income countries - reports a range of $0.7 \%$ to $2.8 \%$ of national healthcare expenditures being attributable to direct costs of obesity in the reported countries (Withrow 2011). A review, limited to studies from the USA, also took direct costs for overweight into consideration. Direct costs of overweight and obesity combined account for $5 \%$ to $10 \%$ of USA healthcare costs (Tsai 2011). In general, indirect costs - highly dependent on which indirect costs are included - can considerably exceed direct costs of overweight and obesity (Dee 2014).

\section{Measurement of obesity}

There is no internationally agreed gold standard for measuring overweight and obesity, as well as a measuring technique to predict the majority of obesity-related health risks (e.g. type 2 diabetes) (Kodama 2012). The BMI is based on a person's weight and height and is one of the surrogate measures most commonly used to estimate total body fat accumulation. However, this measure may produce misleading results, particularly amongst those with high muscle mass, some ethnic groups, and children (Javed 2015; Rahman 2010; Rothman 2008). Common surrogate measures for abdominal obesity specifically include waist circumference (WC), waistto-hip ratio (WHR), and waist-to-height ratio (WHtR) (Ashwell 2012). In recent years, more advanced measurement techniques are used to determine the level of body fat more precisely, such as bioelectrical impedance analysis (BIA), magnetic resonance imaging (MRI), isotope dilution analysis (IDA), ultrasound, and computed tomography (CT) (Kodama 2012; Roubenoff 1995; WHO 2000).

\section{SSBs and obesity}

As stated above, the excessive intake of calories and insufficient physical activity are two of the main drivers for the rise in obesity 
globally. Furthermore, the availability and affordability of energydense foods and changes in eating patterns partly explain the increase in obesity and other health conditions (Drewnowski 2004; Sturm 2014). SSBs substantially contribute to total daily energy intake, especially in high-income countries, but also in middle-income countries (e.g. Mexico) (Bhaumik 2014; Lasater 2011; Stern 2014). As with other countries, added sugar intake of individuals in the USA - based on food sources such as SSBs - is above standard nutritional recommendations (Slining 2013). The most recent WHO guideline strongly recommends that sugar should not exceed $10 \%$ of the total energy intake per day. A daily intake of less than $5 \%$ - approximately 25 grams of sugar for an adult - might lead to even greater health benefits (WHO 2015). By way of comparison, one serving $(330 \mathrm{~mL})$ of a regular SSB contains up to $53 \mathrm{~g}$ of sugar (Action on Sugar 2014). Based on data from national and sub-national dietary surveys as well as data from the Food and Agriculture Organization of the United Nations (FAO), global average daily SSB consumption is estimated to be $137 \mathrm{~mL}$ (95\% confidence interval (CI) $88 \mathrm{~mL}$ to $211 \mathrm{~mL}$ ) for adults (Singh 2015a). Regarding socio-economic and regional patterns, the trend of SSB consumption over the past two decades is twofold: in North America - with high levels of SSB consumption and income - overall SSB demand declined and beverage products with no- or low-caloric sweeteners gained market share, whereas in low- and middle-income countries SSB sales and consumption increased, especially in Asian, Latin American, and African countries (Kit 2013; Popkin 2015; Singh 2015a; Slining 2013). In general, adolescents and young adults consume SSBs more frequently than younger children and older adults. In adulthood, SSB consumption declines with ageing (Han 2013; Singh 2015a). The disproportionate overconsumption of SSBs by children, who are often considered a particularly vulnerable population group, has been seen as providing an important justification for government intervention (Popkin 2015). However, interventions to prevent overweight and obesity throughout the life course should always consider both, children and adults (Lhachimi 2013). In contrast to several other food products (e.g. water, fruits, and vegetables) as recommended in dietary guidelines, SSBs are predominantly not considered to provide unique nutritional and health benefits for the general population in the long run (Colantuoni 2002; Keast 2015; Pan 2011; Poppitt 2015).

\section{SSB intake as a risk factor}

SSBs mainly consist of two components: (1) water and (2) added sugars (e.g. fructose, glucose, sucrose, and maltose). Moreover, companies add various other ingredients in small quantities (e.g. caffeine, citric or phosphoric acids, colour additives) to change the flavour or appearance, or for the effect of SSB products on the human metabolism (Walker 2014). Research on the association between intake of SSBs or their main ingredients and adverse health outcomes considers both physiological and psychological mecha- nisms. From a physiological perspective, this includes diseases and characteristics associated with metabolic syndrome (i.e. abdominal obesity, atherogenic dyslipidaemia, raised blood pressure, insulin resistance, glucose intolerance, prothrombotic state, and proinflammatory state), and dental caries (Bes-Rastrollo 2013; Hauner 2012; Malik 2010; Malik 2013; Sheiham 2014; Te Morenga 2013; Woodward-Lopez 2011). Adverse health outcomes may be supported by the unique characteristics of SSB consumption. In fact, lack of chewing, lack of satiety, endogenous opioid dependences based on sugar as well as caffeine dependences may result in positive feedback loops to consume even greater amounts of SSBs (Colantuoni 2002; Keast 2015; Pan 2011; Poppitt 2015). This also applies to exogenous effects such as ubiquitous SSB marketing by food companies in a competitive market as well as the availability of SSBs in general. Advertising to adults and children (e.g. sponsoring of sport events, television spots for children) to support a positive impression of a brand, together with product placements in stores may guide individual consumer choices. Moreover, parental attitudes to and practices regarding SSB consumption are likely to influence children's attitudes towards SSB consumption (Battram 2016; Wong 2015). Evidence from systematic reviews predominantly shows that excessive consumption of SSBs is linked with an increased risk of weight gain or obesity and associated diseases such as CVD and type 2 diabetes (Bes-Rastrollo 2013; Hauner 2012; Malik 2010; Malik 2013; Sheiham 2014; Te Morenga 2013; Woodward-Lopez 2011). Likewise, an analysis based on data from the Global Burden of Disease study 2010 estimated a total of 184,000 deaths from diabetes (72\%), CVD (24\%), and cancers (4\%) per year and 8.5 million DALYs attributable to SSB consumption (Singh 2015b).

\section{Description of the intervention}

\section{Interventions for preventing or reducing the prevalence of overweight or obesity}

Preventive measures and treatments to tackle overweight and obesity differ in research fields and methodological characteristics (WHO 2000). Medical, educational or lifestyle-related interventions - in the long run - aim either to reduce energy intake or to increase energy expenditure to achieve weight reduction (Roqué i Figuls 2013; von Philipsborn 2016). In addition to interventions at the individual level, food policies such as restrictions (e.g. advertising of food), bans (e.g. banning unhealthy foods from cafeterias), food labelling (e.g. nutrition facts labels), and taxation (e.g. taxes on SSBs) are other options that may support the creation of healthy food environments and help prevent overweight, obesity, dental caries and other non-communicable diseases, particularly among children (Swinburn 2015). Despite limiting consumers' autonomy, policy options such as taxes on SSBs may help to reduce health inequalities in the general population by requiring less 
personal resources of the consumer (e.g. time, health literacy) to stimulate beneficial behaviour (Adams 2016).

\section{Taxes on SSBs}

Food-related fiscal policies may either aim to lower prices (e.g. subsidisation) or increase prices for specific goods (e.g. taxation). We will evaluate the effects of taxes imposed on SSBs. The Organisation for Economic Co-operation and Development (OECD) defines taxes as "compulsory, unrequited payments to general government" (OECD 2014). We will mainly consider two types of payments on products: (1) indirect taxes levied within national borders (e.g. excise tax, sales tax, or value added tax (VAT)), and (2) import taxes including custom duties and import sales taxes (Mytton 2012).

SSB taxes can be considered as Pigouvian taxes and will be evaluated as a fiscal policy in this review. Pigouvian taxes, as introduced by jurisdictions, are intended to correct inefficient allocations of goods in a market (market failure) and reduce costs for the society or a group of individuals that are not directly imposed to the tax (reduction of negative externalities) (Pigou 1932). In the case of SSBs, taxation on these goods aims to correct increased healthcare costs for society and lost productivity, induced by unbalanced diets provoked by the overconsumption of SSBs (Brownell 2009; Strnad 2004). Food taxes might change food consumption patterns as a consequence of changes in food prices (Chriqui 2013; Sassi 2014).

Taxation on SSBs is currently widely discussed in public and scientific research as an intervention to reduce overweight and obesity. However, these taxes can also be introduced with the main motivation to increase government revenue (Chriqui 2008; Maniadakis 2013). Various countries like France, Hungary, Mexico, Pacific Islands countries and territories and various states of the USA have already introduced taxes on SSBs (Ecorys 2014; Mytton 2012; Snowdon 2014). We summarise examples of implemented SSB taxes at national and regional level in Table 1.

The design of SSB taxes mainly varies with regard to three aspects:

1. the definition of which products are taxed as SSBs;

2. the basis for calculating taxation; and

3. the level of taxation (Mytton 2014; Powell 2009; Table 1).

Regarding the first aspect, some jurisdictions levy taxes only on soft drinks, whereas others include a wider spectrum of SSBs (e.g. sweetened fruit juice, sweetened milk) or their ingredients (e.g. instant powder or syrup for quick preparation) (Chriqui 2013). For this review, we define SSBs as non-alcoholic beverages that contain 'free sugars' (e.g. mono- and disaccharides) or other added sugars, such as sodas, fruit drinks, sport drinks, chocolate drinks, sweetened milk, and whey drinks. Moreover, we extend this definition by including ingredients for quick preparation, such as instant powder and syrup, for consumers used to make SSBs (Chriqui 2008; Chriqui 2014; Jou 2012; Mytton 2012; WHO 2015). In a second review conducted in tandem, we will focus on taxes for unprocessed sugar or sugar-added foods (Pfinder 2016). In relation to the second aspect of the design of a SSB tax, the tax can be calculated based on volume, weight, specific item, or the origin of the product (e.g. it may be imposed only on imported SSBs) (Mytton 2012). We will consider all SSB taxes regardless of the basis for tax calculation.

The third aspect deals with different levels, i.e. rates or amounts, of SSB taxes, which can even be present within one country. In the USA, for example, soda sales taxes in food shops differ by state, ranging from $0 \%$ to $7 \%$. Different baseline rates for pre-existing taxes on food, and political aims, can partly explain this variation that affects the relative price increase of SSBs and the capability to curb consumption (Chriqui 2013; Chriqui 2014; Jou 2012). Our review will consider all SSB taxes regardless of the tax level.

\section{How the intervention might work}

Understanding how changes in health might arise, as a consequence of food taxes, can be informed by economic theory - such as the expectation that consumer behaviour will change in response to price changes - and comparative evidence from other taxes on consumer goods with adverse health effects (e.g. taxes on tobacco or alcohol) (Chaloupka 2012; Nederkoorn 2011). For example, taxing tobacco has been proven to decrease overall consumption of tobacco at a population level (Cavazos-Rehg 2014; Chaloupka 2012). Although appropriate energy intake - based on sources like sugar - is crucial for the human metabolism, the consumption of $\mathrm{SSB}$ is not necessarily required to maintain a healthy diet (WHO 2003).

Recent controlled field studies - studies that mimic SSB taxation in clearly defined environments - have shown that increased SSB prices have reduced sales of SSBs and in turn may have encouraged the purchase of food lower in energy (e.g. bottled water and nonsweetened tea). These studies are usually conducted in closed or simulated environments like cafeterias, supermarkets, or utilising vending machines within a particular compound (Block 2010; Epstein 2012; Wansink 2014; Waterlander 2014; Yang 2010).

Empirical evidence is becoming available, based on data from countries or states that have already implemented SSB taxes (Batis 2016; Beradi 2012; Colchero 2016; Kim 2006). This includes research on the association between the existence of state-level soft drink and other high-caloric food taxes, and the incidence of obesity (Kim 2006).

Beyond that, supply-side changes must be considered as well. SSB producers might respond to taxation in various ways (e.g. lowering prices by offering strategic price discounts). As a result, taxes might not be fully passed on to the consumer and this may limit the effectiveness of a tax in improving diets (Maniadakis 2013). In contrast, reformulation of food products as a reaction of producers to avoid taxation may lead to lower energy density of SSB products in general, especially with different tax rates that depend on the sugar content of beverages (Ecorys 2014). A change in demand 
for and substitution of SSBs by the consumption of more diet soda products could increase the impact on general health, and by substituting with drinking water could lead to even greater health benefits for the consumer (e.g. decrease in total energy intake, body weight reduction) (Laviada-Molina 2016; Zheng 2015). Often, subsidisation of healthy foods (e.g. raw vegetables and fruits) financed by revenue gained by taxing unhealthy food is discussed. However, simultaneous subsidisation of healthy food and taxation of unhealthy food might not substantially change consumption patterns due to no change in total expenditure on food and total energy intake (Maniadakis 2013).

VATs tend to be regressive in economic terms; thus, low-income groups have to spend more of their income-share than high-income groups to purchase taxed food items. This could cause an increase in economic inequality (Brownell 2009; Fletcher 2010; Sassi 2014). Despite this, people from lower-income groups are generally more likely to experience greater health benefits due to their greater health burden and their higher price sensitivity, leading to lower consumption (Eyles 2012; Maniadakis 2013). If SSB taxes were ineffective in lowering consumption of SSBs, then in relative terms SSB taxes would risk the disposable income of people with lower income more than the disposable income of people with higher income. This could lead, in turn, to adverse health effects (i.e. intervention-generated health inequalities) (Lorenc 2013).

\section{Logic model}

To conceptualise our research focus on SSB taxation, we developed a logic model with causal pathways for the relationship between SSB taxation and obesity as well as other health outcomes (Anderson 2011a). Figure 1 outlines the underlying issues and assumed causal pathways for this review. We will discuss these pathways in turn. SSB taxation - introduced by local, regional, national, or international governments - is likely to alter the prices of SSBs (Epstein 2012; Jensen 2013; Maniadakis 2013). In market economies, prices of traded goods are influenced by demand and supply (Bonnet 2013). Amongst other factors, the financial resources of individuals (e.g. income) - influenced by individual expenditure on food and other products - determine the demand for food products. These market components might affect consumer purchases and consumption choices of different food categories, including SSBs (Briggs 2013; Sharma 2014). For instance, consumers may substitute taxed food items - in this particular case, SSBs - by purchasing other (food) products (Fowler 2015; Yang 2010). As a consequence, shifts of consumption and substitution patterns result in changes of sugar intake, as well as the intake of other nutrients (Epstein 2012; Laviada-Molina 2016; Maniadakis 2013).

Figure I. Logic/Causal-Pathway Model of SSB taxation
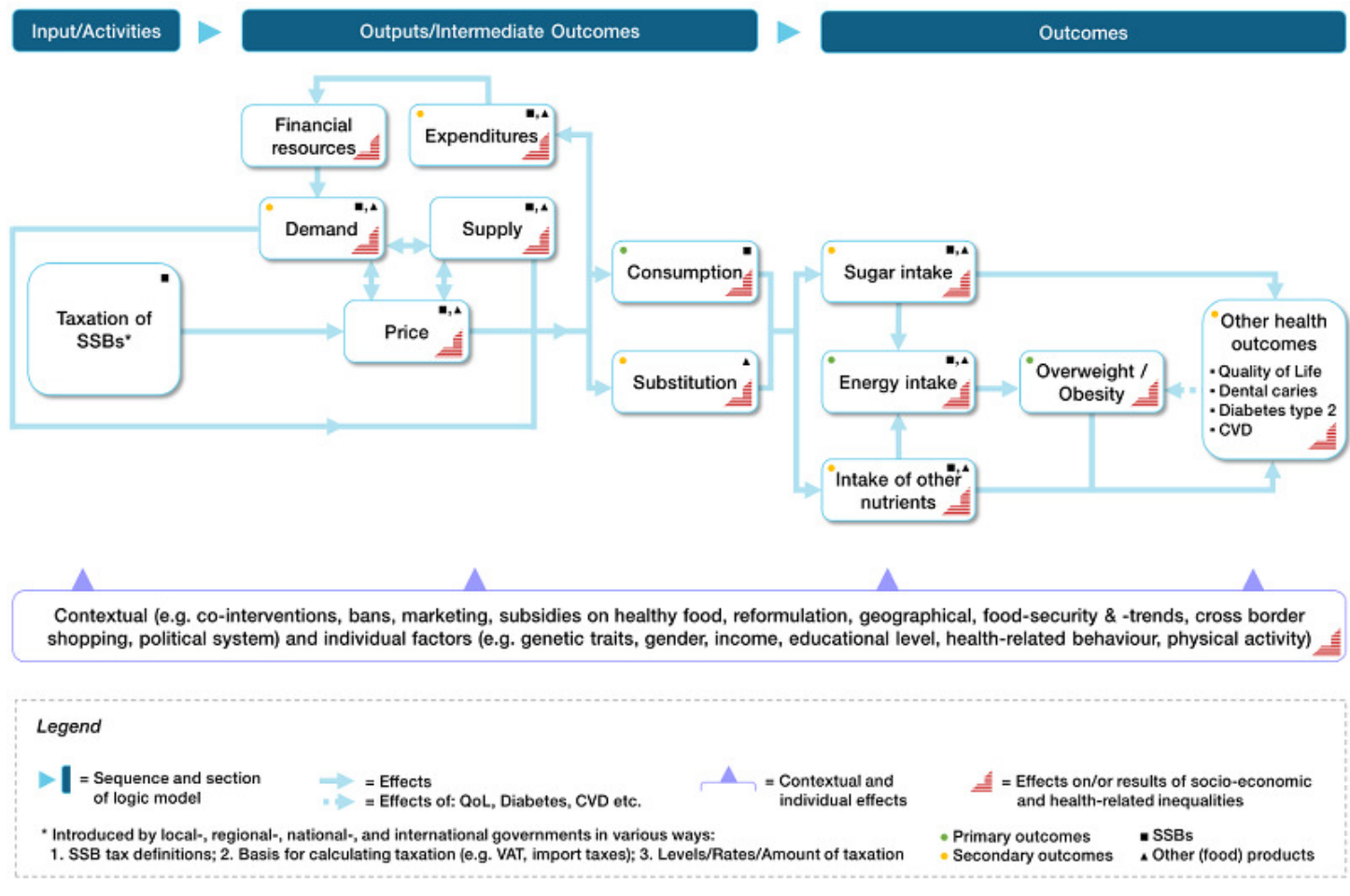

Taxation of sugar-sweetened beverages for reducing their consumption and preventing obesity or other adverse health outcomes 
We will review health outcomes directly or indirectly influenced by changes in consumption as a result of SSB taxation. First, excessive sugar intake is directly associated with various diseases such as dental caries (Moynihan 2014; WHO 2015). Second, sugar intake and other sources of energy (e.g. fat, protein) jointly contribute to the general energy intake. Hence, overconsumption of either sugar or other energy-dense nutrients can support imbalanced energy intake, resulting in higher risks of becoming overweight or obese (Kim 2006; Malik 2013). Overweight and obesity in turn can be a risk factor for other unfavourable health outcomes (e.g. type 2 diabetes, CVD) (Guh 2009). Although SSB consumption seems to have no direct link to health-related quality of life (HRQoL), obesity is known to be associated with lower HRQoL (Jia 2005; Lana 2015; Ul-Haq 2013). The intake of non-caloric nutrients - in particular essential vitamins (e.g. vitamin D) and dietary minerals (e.g. sodium) - can also be affected by changes in consumption and substitution patterns. Therefore, an unbalanced diet that is deficient in non-caloric nutrients has the potential to negatively impact health outcomes as well (Marriott 2010).

Contextual and individual factors may influence the processes from the input to the outcomes, alter effect sizes and help us understand causal relationships (Qi 2012). Effects of competing and complementary interventions (e.g. product bans and marketing restrictions) - possible comparators in this review - and other SSBrelated activities by governments, community, and the food industry might overlap with the effects of SSB taxation (Jou 2012; Thow 2011). Individual factors (e.g. gender, education) are of utmost importance to identify equity issues (Anderson 2011b; Figure 1).

\section{Why it is important to do this review}

The primary motivation for taxing SSBs is to decrease the intake of these beverages in the general population, with the aim of ultimately improving health outcomes. Various Cochrane reviews related to overweight and obesity already exist. These mainly focus on medical, educational, and lifestyle-related interventions with regard to individuals or at-risk groups (Roqué i Figuls 2013). There is no Cochrane review summarising the effects of food-related fiscal measures at present.

Existing systematic reviews on SSB taxation have predominantly synthesised evidence from simulation studies or simulation studies mixed with empirical studies, and predict improvements in diet; i.e. reduced consumption and energy intake from SSBs (Brambila-Macias 2011; Eyles 2012; Maniadakis 2013; Niebylski 2015; Powell 2013; Thow 2014). For example, results of included studies of one review demonstrate a proportional relationship between the applied tax level and the decrease in consumption. The review reports a range of tax levels from $10 \%$ to $20 \%$ where effects on targeted food consumption are consistent (Thow 2014).
Even so, evidence from simulation studies has various methodological limitations. For example, pass-on rates to the consumers must be based upon predictions, supply-side changes cannot be fully captured, and health outcomes are mostly based on static weight change models (Lin 2011; Shemilt 2015).

However, the complex interactions of consumption patterns in response to price changes result in opaque health effects for real implementation (Faulkner 2011). A review of experimental studies on food price changes suggests that a decrease in consumption of SSBs could be substituted by equally or even more unhealthy foods or behaviours (Epstein 2012). Therefore, the discussion and evaluation of current and future implementation of SSB taxes should be based on evidence from empirical primary studies on the effects on health and not only on sales or consumption (Bhaumik 2014; Cornelsen 2013; Mytton 2012). Given that obesity remains a major global health challenge and SSBs account for a considerable share of total daily energy intake, especially for children, a Cochrane review on the effects of SSB taxation is important (Bhaumik 2014).

This research will be part of a set of reviews on different types of food taxes carried out by the same author group using a similar methodological approach. For reasons of comparability, the methodological content is similar across the three reviews. Our three reviews will focus on the effects of governmental taxation of: (1) SSBs, (2) unprocessed sugar or sugar-added foods (Pfinder 2016), and (3) the fat content of foods (Lhachimi 2016).

\section{O B J E C T I VES}

To assess the effects of taxation of sugar-sweetened beverages (SSBs) on SSB consumption, energy intake, overweight, obesity, and other adverse health outcomes in the general population.

\section{METHODS}

\section{Criteria for considering studies for this review}

\section{Types of studies}

Pre-screening of studies evaluating implemented SSB taxation revealed heterogeneous study designs and inherent limitations. Besides small field studies, individual and cluster randomisation are probably impossible for evaluations of SSB interventions at the national level (Wansink 2014). Meanwhile, methodological limitations inevitably derive from the lack of blinding of participants and 
study personnel for the major intervention component - changes in prices of SSB products (Block 2010).

We will therefore consider evidence from various study designs and adopt a similar approach previously used in at least two other Cochrane reviews to summarise 'best available evidence' (Gruen 2004; Turley 2013). This approach clearly separates studies into two broad categories: (1) studies meeting rigorous Cochrane Effectice Practice and Organisation of Care (EPOC) criteria, and (2) supporting studies - those not meeting EPOC criteria with greater risk of bias.

First, for the synthesis of main results, in line with EPOC criteria we will include:

- randomised controlled trials (RCTs);

- cluster randomised controlled trials (cRCTs);

- non-randomised controlled trials (nRCTs);

- controlled before-after (CBA) studies; and

- interrupted time series (ITS) studies.

According to EPOC, controlled studies require more than one intervention or control site and ITS studies require a clearly defined intervention time and at least three data points before and three after the intervention (EPOC 2013).

There will be no restriction by publication date and language, but only studies focusing on human populations will be included (CPH 2011).

We will have no restriction in terms of study duration. Closed field experiments suggest consumer behaviour adaptations expressed as SSBs sales occur within a short time frame; substantial effects become apparent even in one month (Block 2010). Implementation of SSB taxes at a national level might feature a longer time lag between intervention and outcomes, especially for health outcomes. In contrast, after one year of the SSB tax in Mexico, purchases of taxed SSBs as an important intermediate outcome already dropped on average by about $6 \%$ (Popkin 2015). In general, field experiments on SSBs recruit small numbers of participants. Nevertheless, they are a valuable source to identify important outcome pathways and effects on food patterns relevant to SSB taxation (Epstein 2012).

We will exclude simulation studies, due to their potential limitations provoked by their basic assumptions (e.g. lack of potential supply-side changes, static models to predict weight loss), and other methodological restrictions (e.g. the use of a combination of heterogeneous data sources) (Lin 2011; Shemilt 2015).

\section{Supporting studies}

We will include as supporting studies:

- studies using an RCT, cRCT, nRCT, CBA or ITS design but not fulfilling the EPOC criteria (hence, not included in the main results as outlined above);

- prospective cohort studies;

- retrospective or non-concurrent cohort studies;
- repeated cross-sectional studies; and

- uncontrolled before-after (UBA) studies.

Those studies classified as 'supporting studies' will not be included in the statistical synthesis of the primary included studies (i.e. those meeting EPOC criteria) but will be synthesised narratively in addition to the main findings. We will extract the same type of data from these supporting studies as from the included studies and will document these in a separate 'Characteristics of supporting studies' table. We will carry out 'Risk of bias' assessments on these studies, and undertake quality assessment, utilising the GRADE approach, and present the findings from these supporting studies separately, as supplemental information in the results section and in separate 'Summary of findings' tables. Observations of similarities and/or differences of findings from the included studies and the supporting studies will be made in the 'Discussion' section, to help summarise the breadth, quality and the findings of the totality of research on the effects of these interventions.

These studies may support or challenge results in the main findings and highlight uncertainty and potential research gaps. We will consider known limitations of UBA, cohort, and repeated crosssectional studies, especially confounding and/or time trends, in assessing these studies for inclusion. If UBA, cohort, and repeated cross-sectional studies are likely to be biased and do not use appropriate analytic strategies (e.g. stratification) or other designs (e.g. regression discontinuity) to control for known confounders and/ or time trends, we will consider excluding these studies from the 'supporting studies' category of the review.

\section{Types of participants}

We will include studies irrespective of participants' gender and age (children: 0 to 17 years, and adults: 18 years and over) from any country and setting.

We will exclude studies investigating the effects of taxing SSBs focusing on specific subgroups that have higher or lower health risks at baseline or post-intervention phase compared to the general population, particularly:

- people receiving a pharmaceutical intervention;

- people undergoing a surgical intervention;

- pregnant females;

- professional athletes;

- ill people who are overweight or obese as a side-effect of their treatment or condition, such as those with thyroiditis and depression; and

- people with chronic illness(es).

\section{Types of interventions}

This review will include studies that evaluate the effects of SSB taxation. We will examine studies with taxed beverages that contain added caloric sweeteners or ingredients for quick preparation 
that are used by consumers to make SSBs. A SSB tax can variously be described as sales tax, excise, special VAT, custom duties or import tax on the final product sold to the consumer (Chriqui 2008; Chriqui 2013; Jou 2012; Mytton 2012). We will include interventional studies on SSB taxation of any taxation level, provided for any duration, and studies that evaluate effects of artificial price increases of SSBs that mimic SSB taxation in clearlydefined environments (e.g. cafeterias, supermarkets, and vending machines) (Epstein 2012). Interventions can be at the local, regional, national, and international levels or field scenarios that imitate taxation effects. We will include studies with any control intervention, such as no intervention, as well as other food taxes, bans, minimum pricing, media campaigns, or subsidies on healthy foods (Jou 2012; Thow 2011).

\section{Types of outcome measures}

Our outcome selection and grouping was guided by preliminary evidence as discussed in the Background section, on the basis of the logic model and after feedback from the review advisory board members (email and online survey) (How the intervention might work; Table 2). All pre-selected outcomes achieved 'critical' or 'important' ratings on average, following the GRADE approach (GRADE 2013). For primary outcomes we favoured outcomes of critical importance in line with our review scope and objective (Table 3). Detailed information on advisory group involvement is provided under the subheading 'Advisory group' in the section Searching other resources.

Primary outcomes include intermediate outcomes (SSB consumption and energy intake) which are directly affected by tax-induced changes in SSB prices that are on the pathway to health harms. These outcomes may directly alter the primary health outcomes: overweight and obesity. Secondary outcomes will focus on food patterns (substitution and diet), expenditures, and other health outcomes directly or indirectly influenced by SSB taxation. We include demand as a proxy for SSB consumption (see How the intervention might work).

\section{Primary outcomes}

The review will include changes from baseline to post-intervention, in the following primary outcomes:

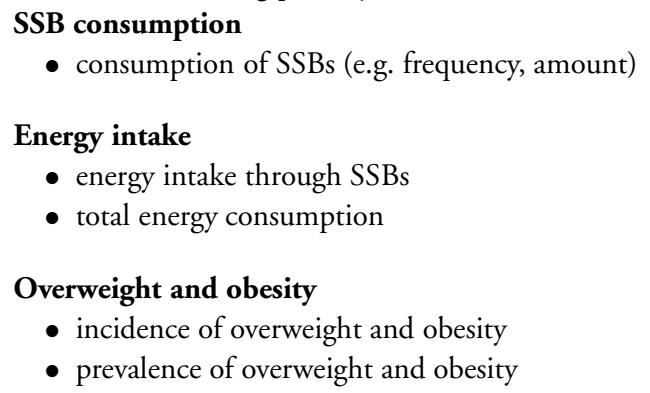

All primary outcomes can be measured by physicians and other professionals or self-reported. Overweight and obesity can be measured by different anthropometric body mass indices (e.g. body mass index (BMI), waist circumference (WC), waist-to-hip ratio (WHR), waist-to-height ratio (WHtR), bioelectrical impedance analysis (BIA), magnetic resonance imaging (MRI), isotope dilution analysis (IDA), computed tomography (CT), etc.). We will report changes in body mass indices if no data are available on the incidence or prevalence of overweight and obesity.

\section{Secondary outcomes}

The review will include changes from baseline to post-intervention in the following secondary outcomes:

\section{Substitution and diet}

- composition of diet (expressed as food groups or ingredients, e.g. fat, sugar, salt)

\section{Expenditures}

- total expenditures on food

- total expenditures on SSBs

\section{Demand}

- total sales of SSBs

\section{Other health outcomes}

- health-related quality of life (e.g. Short Form 36 (SF-36), Health-Related Quality of Life (HRQOL-14))

- mortality

- any other health outcomes or health-related unintended consequences (e.g. dental caries, type 2 diabetes, cardiovascular diseases, etc.)

All secondary outcomes can be measured by physicians and other professionals or self-reported.

\section{Search methods for identification of studies}

\section{Electronic searches}

We will search the following 12 bibliographic databases:

- Cochrane Central Register of Controlled Trials

(CENTRAL) via Cochrane Library (1948 to present)

- Cochrane Database of Systematic Reviews (CDSR) via Cochrane Library (1995 to present)

- Medical Literature Analysis and Retrieval System Online (MEDLINE) via OvidSP (1946 to present)

- Excerpta Medica database (Embase) via OvidSP (1947 to present)

- PsycINFO via OvidSP (1887 to present)

- Current Contents Medicine Database of German and German-Language Journals (CC MED) via LIVIVO (2000 to present) 
- Latin American and Caribbean Health Science Information database (LILACS) via BIREME/VHL (1982 to present)

- EconLit via EBSCO (1969 to present)

- Campbell Library via Campbell Collaboration (2004 to present)

- Food Science and Technology Abstracts (FSTA) via OvidSP (1969 to present)

- Cumulative Index to Nursing and Allied Health Literature (CINAHL) via EBSCO (1937 to present)

- Web of Science (SCI-EXPANDED, SSCI, A\&HCI, CPCIS, CPCI-SSH, ESCI, CCR-EXPANDED, IC) via Thomson Reuters (1900 to present)

We will apply a search strategy with additional keywords for possible comparators (e.g. "subsidy") and we will not use filters for study types, in order to maximise the sensitivity of the literature search (Higgins 2011a, chapter 6.4.4). The search strategy for the MEDLINE database is presented in Appendix 1. We will modify this strategy to fit the syntax of the other databases. We will not include African Index Medicus (AIM) - a valuable resource for literature from low- and middle-income countries (LMICs) - in our review as a sensitive preliminary search with intervention key words (e.g. tax, taxation etc.) resulted in no hits.

\section{Searching other resources}

We will search the following six electronic grey literature databases:

- ProQuest Dissertations \& Theses Database (PQDT) via ProQuest

- System for Information on Grey Literature in Europe (OpenGrey) via INIST/CNRS

- The Directory of Open Access Repositories (OpenDOAR) via $\mathrm{CRC}$

- EconPapers via ORU

- Social Science Research Network (SSRN eLibrary) via SSRN

- National Bureau of Economic Research (NBER) via NBER

We will search the following two databases to identify completed or ongoing studies:

- WHO's International Clinical Trials Registry Platform (WHO ICTRP) (www.who.int/ictrp)

- Trials Register of Promoting Health Interventions (TRoPHI) (eppi.ioe.ac.uk)

\section{Targeted internet searching of key organisational websites}

We will search websites of major organisations and institutions, specifically:

- World Obesity Federation (www.worldobesity.org)

- The Obesity Society (TOS) (www.obesity.org)

- The Organisation for Economic Co-operation and

Development (OECD) (www.oecd.org)

- World Health Organization (WHO) (www.who.int)

- European Commission (EC) (ec.europa.eu/index en.htm)

- Directorate-General for Health and Food Safety (DG

SANTE) (ec.europa.eu/dgs/health ' food-safety/index 'en.htm)

- Centers for Disease Control and Prevention (CDC) (

www.cdc.gov)

- National Institute for Health and Care Excellence (NICE) ( www.nice.org.uk)

- World Trade Organization (WTO) (www.wto.org)

- World Cancer Research Fund Institute (www.wcrf.org)

\section{Searching other resources}

The reference lists of all records of all included studies will be searched by hand.

\section{Advisory group}

We have established a review advisory group of experts in the field of food taxation and health to comment and provide advice and suggestions to inform this review at protocol and review stages. Following the GRADE approach, the advisory group members participated in an online survey and ranked pre-selected outcomes according to their relative importance on a 9-point Likert scale (categories: 1 to 3 - of limited importance; 4 to 6 - important; 7 to 9 - critical) (GRADE 2013). The review advisory group consists of policy makers, researchers, and academics.

We provided the members of the review advisory group with detailed background information on this review. At the protocol stage, the group members were asked to provide feedback specifically on the focus and the relevance of this review's question, selected endpoints, study design, search strategy, database selection, and ongoing or unpublished studies (Higgins 2011a, chapter 2.3.4.3). We received feedback via email and the online survey. All members of the advisory group and results from the online survey are listed in tables (Table 2; Table 3).

\section{Data collection and analysis}

\section{Internet search engines}

The first 30 hits in Google Scholar will be screened. We will use a set of terms from our searches of the academic and grey literature databases.

\section{Selection of studies}

An information specialist will conduct the database searches. If a reference or a full-text paper is not written in English, German, 
or French, the relevant content will be translated to English by using internet-based translators or we will ask for a translated version by contacting native speakers (e.g. colleagues from cooperating research institutes) or the corresponding author of the article. Screening will be conducted in six stages. First, titles of studies, and abstracts if available, will be reviewed by at least two authors independently. If an abstract is not provided by the database it originates from, and the title appears to be potentially relevant, we will progress the record to full-text review stage. Second, both authors will compare their list of relevant studies and in case of any disagreement they will seek the opinion of a third author to achieve consensus. Third, full-text versions of potentially relevant studies will be retrieved or obtained. Fourth, the full-text versions will be screened by the two review authors independently. Fifth, each author will create a list of the studies that are considered to fulfil the inclusion criteria. Sixth, the two authors will compare their list with each other and in case of any disagreement the opinion of a third author will be decisive. Based on these six steps, studies will be selected for inclusion in the review (Higgins 2011a, chapter 7). We will present a flow chart based on PRISMA to depict the selection process (Moher 2009).

\section{Data extraction and management}

Data extraction will be performed independently by at least two authors and both authors will compare the extracted data. Disagreements will be resolved by a third author (Higgins 2011a, chapter 7.6.2). We will use a modified data extraction and assessment template from Cochrane Public Health (CPH) (CPH 2011). Prior to the main data extraction process, the authors will pilot the data extraction form to ensure standardised extraction. We will extract general information (publication type, country of study, funding source for study, potential conflict of interest), study eligibility (type of study, participants, type of intervention, duration of intervention, and type of outcome measures), study details (study aim, methods, results, intervention group, confounders, and confounder-adjusted and unadjusted outcomes), indicators of changes in food prices (price of SSBs, price of other food product categories), and other relevant information (CPH 2011). Effect estimates for study populations based on PROGRESS categories (place of residence, race/ethnicity/culture/language, occupation, gender/sex, religion, education, socio-economic status (SES), social capital) will be extracted to evaluate impacts on equity. We will also extract other contextual factors (political system, co-interventions, reason for implementation, reason for certain tax level, intended beneficiaries, implementation costs, country- and region-specific level of gross domestic product (GDP), food security (availability, access, and use) and process evaluation criteria (e.g. satisfaction of participants, adherence)) that facilitate or hinder the implementation of SSB taxation (Anderson 2011b). Data will be entered into Review Manager 5 (RevMan 2014) by one author. A second author will double-check the data entered.

\section{Assessment of risk of bias in included studies}

The risk of bias of every included study will be evaluated independently by at least two authors. In case of any disagreement, discrepancies will be discussed with a third author and resolved by consensus. Based on the template provided by $\mathrm{CPH}$, the risk of bias will be assessed using the criteria for judging risk of bias in Cochrane's 'Risk of bias' assessment tool and the Cochrane Effective Practice and Organisation of Care (EPOC) Group's guidance (CPH 2011). Both tools examine the following biases: selection, performance, detection, attrition, reporting, and other (EPOC 2009; Higgins 2011b). For interrupted time series (ITS) the EPOC 'Risk of bias' tool examines three further risks of bias: "Was the intervention independent of other changes?", "Was the shape of the intervention effect pre-specified?", and "Was the intervention unlikely to affect data collection?" (EPOC 2009). For studies included in the main analysis (i.e. RCTs, cRCTs, nRCTs, CBA, and ITS) we will assess the risk of bias using the 'Risk of bias' criteria for EPOC reviews, based on the Cochrane Collaboration's tool for assessing risk of bias (Higgins 2011a, Table 8.5.a).

Risk of bias of 'supporting studies' (i.e. studies not fulfilling EPOC criteria, cohort studies, repeated cross-sectional studies, UBA) will be assessed with the Quality Assessment Tool for Quantitative Studies, developed by the Effective Public Health Practice Project (EPHPP) (EPHPP 2010).

To judge the risk of bias according to Cochrane's 'Risk of bias' assessment tool, we will use the following categories: "low", "high", and "unclear" (e.g. information is lacking or the risk of bias is unclear) (Higgins 2011a, chapter 8.6). To judge the risk of bias according to the Quality Assessment Tool for Quantitative Studies, we will use the following three categories: "strong", "moderate", and "weak" (EPHPP 2010). We will provide 'Risk of bias' tables for all included studies.

\section{Measures of treatment effect}

Data synthesis aims to combine outcome data. We will report the effects of the treatment on dichotomous outcomes as odds ratios (ORs), risk ratios (RRs) or risk differences (RDs). In accordance with the recommendations from $\mathrm{CPH}$, RRs will be the preferred reported measure of treatment effect (CPH 2011). If RRs are not presented in the study, but data to calculate the RRs are provided, we will calculate them. This also applies for data suitable to calculate ORs (e.g. obesity prevalence). If data to calculate the RRs are not provided, we will contact the corresponding author of the study, by email or phone, to request the RRs or the data to calculate the RRs. If we cannot obtain RRs, we will report the treatment effect from the study report.

We will express continuous data as mean differences (MDs) where applicable or as standardised mean differences (SMDs). Shorter ordinal data will be translated into dichotomous data (expressed as ORs, RRs or RDs) and longer ordinal data will be treated as continuous data (expressed as MDs or SMDs). It is unclear whether 
there is a cut-off point that is common across the studies and can be used for dichotomisation (Higgins 2011a, chapter 7). The cut-off point will be part of the sensitivity analysis. We will express count data and Poisson data as rate ratios. Time-to-event data (survival data) will be translated into dichotomous data when appropriate, or into hazard ratios (HRs).

If feasible, we will report the adjusted treatment effect. If a study does not present adjusted treatment effect measures, we aim to adjust the treatment effect measures for baseline variables by conducting additional multivariate analyses as far as we have access to the data or by contacting the corresponding author of the study for the adjusted treatment effect measures by email or phone. If studies present intention-to-treat effect estimates, then we will prioritise these over average causal treatment effect estimates (Higgins 2011a, chapter 9).

When the treatment effect is described in cost estimates as derived from economic studies, we will convert the cost estimates to US dollars (USD) and the price year 2015 to compare cost estimates from different studies with each other. To convert cost estimates into USD, we will apply an international exchange rate based on Purchasing Power Parities (PPPs). To convert cost estimates to the year 2015, we will apply GDP deflators or implicit price deflators for GDP. PPP conversion rates and GDP deflator values will be derived from the International Monetary Fund in the World Economic Outlook Database (http://www.imf.org/ external/data.htm) (Higgins 2011a, chapter 15).

\section{Unit of analysis issues}

We will collect data on studies irrespective of whether individuals or groups are allocated to an intervention or control group. The analysis will consider the level at which the allocation occurred, e.g. cluster randomised trials, cross-over trials, and multiple observations (repeated observations on subjects, recurring events, multiple body parts, and multiple intervention groups) for the same outcome (Higgins 2011a, chapter 9.3.1). Limited by the quality of reported data, we will consider data from cross-over trials (e.g. by incorporating the study data similar to a parallel group trial) and studies with multiple observations (e.g. by defining different periods of follow-up) (Higgins 2011a, chapter 9.3.4; chapter 16.4.5). If control for clustering is missing or insufficient and individuallevel data are not presented in the study, we will request individual-level data from the contact study author. If feasible, we will reduce the size of each trial to its 'effective sample size' in order to correct intervention effects of cluster randomised trials. The effective sample size of an intervention group is the original sample size divided by the 'design effect'. We will calculate the design effect by the formula $1+(\mathrm{M}-1)$ ICC. $M$ is the average cluster size and ICC is the intracluster correlation coefficient (Higgins 2011a, chapter 16.3.4).

For dichotomous data the total number of participants and the number of participants who experience the event will be divided by the same design effect. For continuous data, only the sample size will be reduced; means and standard deviations will remain unchanged (Higgins 2011a, chapter 16.3.4).

\section{Dealing with missing data}

We will request all missing information and data from principal study authors by email or phone. The following steps will be taken to deal with relevant missing data:

- contact the authors;

- screen the study and investigate important numerical data such as randomised individuals as well as intention-to-treat (ITT), as-treated and per-protocol (PP) populations;

- investigate attrition rates as part of the risk of bias assessment in terms of dropouts, losses to follow-up and withdrawals;

- critically appraise issues of missing data and imputation methods (e.g. last observation carried forward (LOCF));

- impute missing standard deviations if contacted authors do not respond (Higgins 2011a, chapter 16.1); and

- apply sensitivity analyses to estimate the impact of imputation on meta-analyses.

Data 'not missing at random' due to systematic loss to follow-up or systematic exclusion of individuals from studies will be sought and requested from study authors (Higgins 2011a, chapter 16.1.2).

\section{Assessment of heterogeneity}

In the event of substantial heterogeneity (methodological heterogeneity, statistical heterogeneity or considerable differences in the type of study populations, interventions, comparisons, and outcomes (PICO heterogeneity)), we will not perform meta-analysis. Statistical heterogeneity will be detected through visual inspection of the forest plots and by using a standard $\mathrm{Chi}^{2}$ test with a significance level of $\mathrm{P}<0.1$. The $\mathrm{I}^{2}$ statistic will be applied to quantify inconsistency across studies and to assess the impact of heterogeneity on the meta-analysis. Potential reasons for heterogeneity will be examined by conducting theoretically-informed subgroup analyses (Higgins 2011a, chapter 9.5).

Methodological and PICO heterogeneity will be assessed through tabulation and seeking explanations for heterogeneity between study findings. We will consider potential sources of heterogeneity such as:

- study population;

- intervention area/setting;

- intervention characteristics (tax definition, basis for calculating taxation, level of taxation);

- implementation level and duration;

- comparisons;

- co-interventions; and

- outcomes. 


\section{Assessment of reporting biases}

Reporting biases, including publication bias, time lag bias, multiple (duplicate) publication bias, location bias, citation bias, language bias, and outcome reporting bias, occur when the dissemination of research results depends on their magnitude and direction (Higgins 2011a, chapter 10). If we find ten or more studies reporting the same outcome, we will produce and assess funnel plots for study effects resulting from reporting biases. When testing asymmetry in funnel plots (small study effects), we will investigate whether the relationship between a measure of study size and the estimated intervention effect is asymmetrical (Higgins 2011a, chapter 10.4). Funnel plots will be drawn using Review Manager 5 (RevMan 2014).

\section{Data synthesis}

If two or more studies report the same outcome and are sufficiently homogenous conceptually, methodologically, and statistically, we will perform meta-analyses of these studies using Review Manager 5 (RevMan 2014). For dichotomous outcomes we will apply the Mantel-Haenszel method and for continuous outcomes we will apply the inverse variance method. For all analyses, the random-effects method will be applied as we expect differences in the underlying effect sizes due to contextual and implementation differences (Higgins 2011a, chapter 9.5.4). If a study reports two or more measures for the same outcome, then we will report the measure that is most frequently reported by the other included studies. If a study reports multiple follow-ups for the same outcome (e.g. six months during the intervention, one year during the intervention, and six months after the intervention), we will prioritise the longest follow-up during the intervention (e.g. one year during the intervention in the example given). Nevertheless, we will extract all follow-up data.

Study results with insufficient homogeneity will be narratively synthesised. First, we will structure narrative synthesis by outcome categories of this review. Second, within these categories we will make further separation according to intervention setting (i.e. field scenarios, evaluation of implemented SSB taxes) and study design (e.g. RCT, cRCT, nRCT, CBA, and ITS etc.) or study quality (Ryan 2016). In addition to reporting findings as text and tables, we may consider both harvest plots and effect direction plots to summarise data not suitable for meta-analyses. Harvest plots are graphical summaries of data, represented by multiple shaded or non-shaded bars with varying heights. They can be used to indicate effect directions across included studies with non-standardised effect estimates of outcomes (e.g. anthropometric measures). Similarly, effect direction plots can be used to depict information on effect directions with a stronger focus on direct comparisons across studies (Ogilvie 2008; Thomson 2013).

We will provide a 'Summary of findings' table containing the outcomes of greatest interest for decision makers. Therefore, we will include at least the following outcomes: consumption of SSBs, energy intake from SSBs, total energy intake, prevalence of overweight or obesity, and total sales of SSBs. This pre-selected list is based on feedback from our advisory group and external reviewers. This table will include information on the outcomes, comparative risks, the relative effect, the number of participants, the number of studies included, the quality of evidence based on GRADE, and additional comments. If feasible, we will use the computer software GRADEpro to prepare the 'Summary of findings' table (GRADEpro GDT; Higgins 2011a, chapter 11).

Results of data synthesis will also be mapped against our initial logic model, to refine the theory of change and to assess the credibility of the assumed causal pathways.

\section{Subgroup analysis and investigation of heterogeneity}

We will conduct meta-analyses and harvest-plots for studies assessing the following subgroups for primary outcomes, where feasible:

- high-income countries versus middle- and low-income countries;

- high-income groups versus middle- and low-income groups;

- high-educated groups versus low-educated groups;

- different levels of SSB taxes;

- single tax on SSBs versus multiple taxes on SSBs;

- tax on SSBs alone versus tax on SSBs accompanied by other fat taxes or interventions (e.g. bans, minimum pricing, media campaigns, or subsidies of healthy foods);

- different types of taxation: (1) indirect taxes levied within national borders (e.g. excise, sales tax, or VAT), and (2) import taxes including custom duties and import sales taxes;

- children versus adults; and

- BMI subgroups.

If data are available, we will perform subgroup analyses according to dimensions of disadvantage based on PROGRESS categories (e.g. place of residence, gender, education) (Anderson 2011b). If feasible, we will investigate the statistical significance of differences in the treatment effect between subgroups using t-tests and $\mathrm{Chi}^{2}$ tests (Higgins 2011a, chapter 9.6.2).

\section{Sensitivity analysis}

Sensitivity analyses will be performed to determine the robustness of our results by conducting separate meta-analyses and harvest plots for the studies included in our review:

- with studies considered as being at 'low risk of bias' compared to those considered as being at 'high risk of bias';

- with respect to the source of funding;

- with published studies compared to unpublished studies;

- with respect to the intervention duration;

- with respect to the follow-up time;

- with objective measures compared to subjective measures;

- with respect to study design; 
- with respect to cut-off points of the measures of the treatment effect; and

- with respect to imputation of data.

Studies assessed with a high or unclear risk of bias with respect to incomplete outcome data and baseline differences will not be included in these analyses. For cRCTs with adequate data provided, we will perform intra-cluster correlation value sensitivity analysis. We will report findings of sensitivity analyses as a summary table (Higgins 2011a, chapter 9.7).

\section{ACKNOWLEDG EMENTS}

We gratefully acknowledge the contribution of members of our advisory group for their valuable comments and suggestions to im- prove our manuscript: Cristina Cleghorn (Department of Public Health, University of Otago, Wellington, NZ), Emilia Crighton (Faculty of Public Health, London, UK), Peter Faassen de Heer (CMO and Public Health Directorate Scottish Government, Edinburgh, UK), Dionne Mackison (Department for International Development, UK Government, Glasgow, UK), Barry Popkin (Professor of Global Nutrition, University of North Carolina, Chapel Hill, US), and Torben Jørgensen (Professor Department of Public Health University of Copenhagen, Copenhagen, DK). We thank Jodie Doyle (Cochrane Public Health) for editorial guidance. We also thank the reviewers Eva Rehfuess, Patrick Condron, Sreekumaran Nair, and Rob Anderson for their valuable editorial feedback, as well as Kawther Hashem and Annhild Mosdøl for additional external peer referee feedback. Moreover, we acknowledge the contribution of Kylie Thaler for her valuable methodological input to improve the protocol draft.

\section{REFERE N C ES}

\section{Additional references}

\section{Action on Sugar 2014}

Action on Sugar. Soft drinks survey 2014.

www.actiononsalt.org.uk/actiononsugar/

Press\%20Release\%20/133642.pdf (accessed 8 July 2015).

\section{Adams 2016}

Adams J, Mytton O, White M, Monsivais P. Why are some population interventions for diet and obesity more equitable and effective than others? The role of individual agency. PLoS Medicine 2016;13(4):e1001990. [DOI: 10.1371/ journal.pmed.1001990]

American Samoa Bar Association 2015

American Samoa Bar Association. Code annotated: chapter 10 - excise tax on imports. www.asbar.org/index.php? option $=$ com ${ }^{*}$ content $\&$ view $=$ category $\&$ id $=516 \&$ Itemid $=$ 172 (accessed 19 January 2016).

\section{Anderson 2011a}

Anderson LM, Petticrew M, Rehfuess E, Armstrong R, Ueffing E, Baker P, et al. Using logic models to capture complexity in systematic reviews. Research Synthesis Methods 2011;2(1):33-42. [DOI: 10.1002/jrsm.32]

Anderson 2011b

Anderson LM, Petticrew M, Rehfuess E, Armstrong R, Ueffing E, Baker P. Equity checklist for systematic review authors. equity.cochrane.org/sites/equity.cochrane.org/files/ uploads/equitychecklist2011.pdf (accessed 21 April 2015).

\section{Ashwell 2012}

Ashwell M, Gunn P, Gibson S. Waist-to-height ratio is a better screening tool than waist circumference and BMI for adult cardiometabolic risk factors: systematic review and meta-analysis. Obesity Reviews 2012;13(3):275-86. [DOI: 10.1111/j.1467-789X.2011.00952.x]
Australian Taxation Office 2012

Australian Taxation Office. Fact sheet for small business: GST and food. www.ato.gov.au/workarea/ DownloadAsset.aspx?id=9333 (accessed 19 January 2016).

Batis 2016

Batis C, Rivera JA, Popkin BM, Taillie LS. First-year evaluation of Mexico's tax on nonessential energy-dense foods: an observational study. PLoS Medicine 2016;13(7): e1002057. [DOI: 10.1371/journal.pmed.1002057]

\section{Battram 2016}

Battram DS, Piché L, Beynon C, Kurtz J, He M. Sugarsweetened beverages: children's perceptions, factors of influence, and suggestions for reducing intake. Journal of Nutrition Education and Behavior 2016;48(1):27-34.e1. [DOI: 10.1016/j.jneb.2015.08.015]

\section{Beradi 2012}

Berardi N, Sevestre P, Tepaut M, Vigneron A. The impact of a 'Soda Tax' on prices: evidence from French micro data (December 2012). Banque de France Working Paper No. 415. ssrn. com/abstract $=2192470$ (accessed 19 January 2016).

\section{Bes-Rastrollo 2013}

Bes-Rastrollo M, Schulze MB, Ruiz-Canela M, MartinezGonzalez MA. Financial conflicts of interest and reporting bias regarding the association between sugar-sweetened beverages and weight gain: a systematic review of systematic reviews. PLoS Medicine 2013;10(12):e1001578. [DOI: 10.1371/journal.pmed.1001578]

\section{Bhaumik 2014}

Bhaumik S. The public health threat from sugary drinks in India. BMJ 2014;349:g6216. [DOI: 10.1136/bmj.g6216] 
Block 2010

Block JP, Chandra A, McManus KD, Willett WC. Pointof-purchase price and education intervention to reduce consumption of sugary soft drinks. American Journal of Public Health 2010;100(8):1427-33. [DOI: 10.2105/ ajph.2009.175687]

\section{Bonnet 2013}

Bonnet C, Requillart V. Impact of cost shocks on consumer prices in vertically-related markets: the case of the French soft drink market. American Journal of Agricultural Economics 2013;95(5):1088-108. [DOI: 10.1093/ajae/ aat055]

\section{Brambila-Macias 2011}

Brambila-Macias J, Shankar B, Capacci S, Mazzocchi M, Perez-Cueto FJ, Verbeke W, et al. Policy interventions to promote healthy eating: a review of what works, what does not, and what is promising. Food and Nutrition Bulletin 2011;32(4):365-75. [PUBMED: 22590970]

\section{Briggs 2013}

Briggs AD, Mytton OT, Kehlbacher A, Tiffin R, Rayner $\mathrm{M}$, Scarborough P. Overall and income specific effect on prevalence of overweight and obesity of $20 \%$ sugar sweetened drink tax in UK: econometric and comparative risk assessment modelling study. BMJ 2013;347:f6189. [DOI: 10.1136/bmj.f6189]

\section{Brownell 2009}

Brownell KD, Farley T, Willett WC, Popkin BM, Chaloupka FJ, Thompson JW, et al. The public health and economic benefits of taxing sugar-sweetened beverages. The New England Journal of Medicine 2009;361(16):1599-605. [DOI: 10.1056/NEJMhpr0905723]

\section{Cavazos-Rehg 2014}

Cavazos-Rehg PA, Krauss MJ, Spitznagel EL, Chaloupka FJ, Luke DA, Waterman B, et al. Differential effects of cigarette price changes on adult smoking behaviours. Tobacco Control 2014;23(2):113-8. [DOI: 10.1136/ tobaccocontrol-2012-050517]

\section{Chaloupka 2012}

Chaloupka FJ, Yurekli A, Fong GT. Tobacco taxes as a tobacco control strategy. Tobacco Control 2012;21(2): 172-80. [DOI: 10.1136/tobaccocontrol-2011-050417]

\section{Chan 2010}

Chan RS, Woo J. Prevention of overweight and obesity: how effective is the current public health approach. International Journal of Environmental Research and Public Health 2010;7(3):765-83. [DOI: 10.3390/ijerph7030765]

\section{Chriqui 2008}

Chriqui JF, Eidson SS, Bates H, Kowalczyk S, Chaloupka FJ. State sales tax rates for soft drinks and snacks sold through grocery stores and vending machines, 2007. Journal of Public Health Policy 2008;29(2):226-49. [DOI: 10.1057/jphp.2008.9]

\section{Chriqui 2013}

Chriqui JF, Chaloupka FJ, Powell LM, Eidson SS. A typology of beverage taxation: multiple approaches for obesity prevention and obesity prevention-related revenue generation. Journal of Public Health Policy 2013;34(3): 403-23. [DOI: 10.1057/jphp.2013.17]

\section{Chriqui 2014}

Chriqui JF, Eidson SS, Chaloupka FJ. State sales taxes on regular soda (as of January 1, 2014). www.bridgingthegapresearch.org/' asset/s2b5pb/ BTG' soda tax' fact' sheet April2014.pdf. University of Illinois at Chicago, (accessed 30 April 2015).

\section{City of Berkeley 2014}

City of Berkeley. Charter of the City of Berkeley: chapter 7.72 sugar-sweetened beverage product distribution tax. www.codepublishing.com/CA/Berkeley/?Berkeley07/ Berkeley0772/Berkeley0772.html (accessed 19 January 2016).

\section{City of Philadelphia 2016}

City of Philadelphia. Amending title 19 of the Philadelphia Code, entitled "Finance, Taxes and Collections," by adding a new chapter 19-4100, entitled "Sugar-Sweetened Beverage Tax," under certain terms and conditions. phila.legistar.com/View.ashx?M=F\&ID=4526809\&GUID= 545BEB2B-9D57-4919-9EED-977A807EDF76 (accessed 19 July 2016).

\section{Colantuoni 2002}

Colantuoni C, Rada P, McCarthy J, Patten C, Avena NM, Chadeayne A, et al. Evidence that intermittent, excessive sugar intake causes endogenous opioid dependence. Obesity Research 2002;10(6):478-88. [DOI: 10.1038/oby.2002.66]

\section{Colchero 2016}

Colchero MA, Popkin BM, Rivera JA, Ng SW. Beverage purchases from stores in Mexico under the excise tax on sugar sweetened beverages: observational study. BMJ 2016; 352:h6704. [DOI: 10.1136/bmj.h6704]

\section{Cornelsen 2013}

Cornelsen L, Green R, Dangour AD, Smith RD. Is a tax on sugary drinks too bitter to swallow?. BMJ 2013;347:f7039. [DOI: 10.1136/bmj.f7039]

\section{CPH 2011}

Cochrane Public Health. Guide for developing a Cochrane protocol. ph.cochrane.org/sites/ph.cochrane.org/files/ uploads/Guide for $\mathrm{PH}$ protocol ${ }^{\circ}$ Nov $2011^{\prime}$ final for website.pdf (accessed 25 June 2015).

\section{Dee 2014}

Dee A, Kearns K, O’Neill C, Sharp L, Staines A, O’Dwyer $\mathrm{V}$, et al. The direct and indirect costs of both overweight and obesity: a systematic review. BMC Research Notes 2014; 7:242. [DOI: 10.1186/1756-0500-7-242]

\section{Dinsa 2012}

Dinsa GD, Goryakin Y, Fumagalli E, Suhrcke M. Obesity and socioeconomic status in developing countries: a systematic review. Obesity Reviews 2012;13(11):1067-79. [DOI: 10.1111/j.1467-789X.2012.01017.x] 


\section{Drewnowski 2004}

Drewnowski A, Specter SE. Poverty and obesity: the role of energy density and energy costs. American Journal of Clinical Nutrition 2004;79(1):6-16.

\section{Ecorys 2014}

Ecorys, Euromonitor, IDEA, DTI. Food taxes and their impact on competitiveness in the agri-food sector: annexes to the Main report. ec.europa.eu/DocsRoom/documents/ 6150/attachments/1/translations/en/renditions/pdf (accessed 25 July 2015).

\section{EPHPP 2010}

Effective Public Health Practice Project (EPHPP). Quality assessment tool for quantitative studies. www.ephpp.cal PDF/Quality\%20Assessment\%20Tool'2010'2.pdf (accessed 29 July 2015)

\section{EPOC 2009}

Effective Practice and Organisation of Care group (EPOC). Suggested risk of bias criteria for EPOC reviews. epoc.cochrane.org/ sites/epoc.cochrane.org/files/uploads/Suggested $\% 20$ risk\%20of\%20bias\%20criteria\%20for\%20EPOC\%20reviews.pdf\%202015.pdf (accessed 19 January 2016). (accessed 25 July 2015).

\section{EPOC 2013}

Effective Practice and Organisation of Care group (EPOC). What study designs should be included in an EPOC review? . epoc.cochrane.org/sites/epoc.cochrane.org/files/uploads/ 05\%20What $\% 20$ study\%20designs $\% 20$ should $\% 20$ be $\% 20$ included $\% 20$ inernment of Norway 2015 (accessed 1 December 2015).

\section{Epstein 2012}

Epstein LH, Jankowiak N, Nederkoorn C, Raynor HA, French SA, Finkelstein E. Experimental research on the relation between food price changes and foodpurchasing patterns: a targeted review. American Journal of Clinical Nutrition 2012;95(4):789-809. [DOI: 10.3945/ ajcn.111.024380]

\section{Ernst \& Young 2015}

Ernst, Young. Focus on Barbados budget: 2015. www.ey.com/Publication/vwLUAssets/EY-barbadosbudget-2015-2016/\$FILE/EY-barbados-budget-20152016.pdf (accessed 19 January 2016).

\section{Eyles 2012}

Eyles H, Ni Mhurchu C, Nghiem N, Blakely T. Food pricing strategies, population diets, and non-communicable disease: a systematic review of simulation studies. PLoS Medicine 2012;9(12):e1001353. [DOI: 10.1371/ journal.pmed.1001353]

Faulkner 2011

Faulkner GE, Grootendorst P, Nguyen VH, Andreyeva T, Arbour-Nicitopoulos K, Auld MC, et al. Economic instruments for obesity prevention: results of a scoping review and modified Delphi survey. International Journal of Behavioral Nutrition and Physical Activity 2011;8:109. [DOI: 10.1186/1479-5868-8-109]

\section{Fletcher 2010}

Fletcher JM, Frisvold D, Tefft N. Can soft drink taxes reduce population weight?. Contemporary Economic Policy 2010;28 (1):23-35. [DOI: 10.1111/j.1465-7287.2009.00182.x]

\section{Fowler 2015}

Fowler SPG, Williams K, Hazuda HP. Diet soda intake is associated with long-term increases in waist circumference in a biethnic cohort of older adults: the San Antonio Longitudinal Study of Aging. Journal of the American Geriatrics Society 2015;63(4):708-15. [DOI: 10.1111/ jgs.13376]

\section{Goni 2015}

Goni L, Cuervo M, Milagro FI, Martinez JA. A genetic risk tool for obesity predisposition assessment and personalized nutrition implementation based on macronutrient intake. Genes \& Nutrition 2015;10(1):445. [DOI: 10.1007/ s12263-014-0445-z]

Government of Dominica 2015

Government of Dominica. Excise tax (amendment). www.dominica.gov.dm/laws/2015/ Excise $\% 20$ Tax\%20\%20\%28Amd\%29\%20Order,

Government of Mauritius 2015

Government of Mauritius. Excise Act 1994: amendments - MRA Act 2004. www.mra.mu/download/ ExciseAct041115.pdf (accessed 19 January 2016).

Government of Norway 2015 2016]. www regieringen no/no/tema/okonomi-og-budsjett/ skatter-og-avgifter/avgiftssatser-i-2015-og-foreslatte-satserfor-2016 (accessed 19 January 2016).

Government of St Helena 2013 Government of St Helena. Chapter 145: customs and excise ordinance and subsidiary legislation. www.sainthelena.gov.sh/wp-content/uploads/2013/01/145Customs-Ordinance-3107128.pdf (accessed 19 January 2016).

\section{Government of the Republic of Nauru 2010}

Government of the Republic of Nauru. Customs (Rates of Duty) Act 2010. ronlaw.gov.nr/nauru lpms/files/acts/ 2504a62e4138bb1d8c60983907db3035.pdf (accessed 19 January 2016).

\section{Government of Vanuatu 2015}

Government of Vanuatu. Laws of the Republic of Vanuatu - consolidated edition 2015: chapter 290. customsinlandrevenue.gov.vu/ images/legislations/Official ' Gazette/ Excise ActCAP '2902015 ' Consolidated 'Edition '2015.pdf (accessed 19 January 2016).

\section{GRADE 2013}

GRADE Working Group. Handbook for grading the quality of evidence and the strength of recommendations using the GRADE approach. Updated October 2013. www.guidelinedevelopment.org/handbook/ (accessed 26 May 2015). 
GRADEpro GDT [Computer program]

GRADE Working Group, McMaster University. GRADEpro GDT. Version accessed 09 August 2016. Hamilton (ON): GRADE Working Group, McMaster University, 2014.

\section{Gruen 2004}

Gruen RL, Weeramanthri TS, Knight SE, Bailie RS. Specialist outreach clinics in primary care and rural hospital settings. Cochrane Database of Systematic Reviews 2004, Issue 1. [DOI: 10.1002/14651858.CD003798.pub2]

\section{Guh 2009}

Guh D, Zhang W, Bansback N, Amarsi Z, Birmingham CL, Anis A. The incidence of co-morbidities related to obesity and overweight: a systematic review and meta-analysis. BMC Public Health 2009;9(1):88. [DOI: 10.1186/ 1471-2458-9-88]

\section{Hall 2011}

Hall KD, Sacks G, Chandramohan D, Chow CC, Wang YC, Gortmaker SL, et al. Quantification of the effect of energy imbalance on bodyweight. Lancet 2011;378(9793): 826-37. [DOI: 10.1016/S0140-6736(11)60812-X]

Han 2013

Han E, Powell LM. Consumption patterns of sugarsweetened beverages in the United States. Journal of the Academy of Nutrition and Dietetics 2013;113(1):43-53. [DOI: 10.1016/j.jand.2012.09.016]

\section{Hauner 2012}

Hauner H, Bechthold A, Boeing H, Bronstrup A, Buyken A, Leschik-Bonnet E, et al. Evidence-based guideline of the German Nutrition Society: carbohydrate intake and prevention of nutrition-related diseases. Annals of Nutrition and Metabolism 2012;60(suppl 1):1-58. [DOI: 10.1159/ 000335326]

\section{Higgins 2011a}

Higgins JPT, Green S (editors). Cochrane Handbook for Systematic Reviews of Interventions Version 5.1.0 [updated March 2011]. The Cochrane Collaboration, 2011. Available from www.cochrane-handbook.org.

\section{Higgins 2011b}

Higgins JPT, Altman DG, Gøtzsche PC, Jüni P, Moher D, Oxman AD, et al. The Cochrane Collaboration's tool for assessing risk of bias in randomised trials. BMJ 2011;343: d5928. [DOI: 10.1136/bmj.d5928]

\section{Hill 2006}

Hill JO. Understanding and addressing the epidemic of obesity: an energy balance perspective. Endocrine Reviews 2006;27(7):750-61. [DOI: 10.1210/er.2006-0032]

\section{Javed 2015}

Javed A, Jumean M, Murad MH, Okorodudu D, Kumar $S$, Somers VK, et al. Diagnostic performance of body mass index to identify obesity as defined by body adiposity in children and adolescents: a systematic review and metaanalysis. Pediatric Obesity 2015;10(3):234-44. [DOI: 10.1111/ijpo.242]

\section{Jensen 2013}

Jensen JD, Smed S. The Danish tax on saturated fat - short run effects on consumption, substitution patterns and consumer prices of fats. Food Policy 2013;42:18-31. [DOI 10.1016/j.foodpol.2013.06.004]

Jia 2005

Jia H, Lubetkin EI. The impact of obesity on health-related quality-of-life in the general adult US population. Journal of Public Health 2005;27(2):156-64. [DOI: 10.1093/ pubmed/fdi025]

Jou 2012

Jou J, Techakehakij W. International application of sugarsweetened beverage (SSB) taxation in obesity reduction: factors that may influence policy effectiveness in countryspecific contexts. Health Policy 2012;107(1):83-90. [DOI: 10.1016/j.healthpol.2012.05.011]

Juonala 2011

Juonala M, Magnussen CG, Berenson GS, Venn A, Burns TL, Sabin MA, et al. Childhood adiposity, adult adiposity, and cardiovascular risk factors. New England Journal of Medicine 2011;365(20):1876-85. [DOI: 10.1056/ NEJMoa1010112]

\section{Keast 2015}

Keast RS, Swinburn BA, Sayompark D, Whitelock S, Riddell LJ. Caffeine increases sugar-sweetened beverage consumption in a free-living population: a randomised controlled trial. British Journal of Nutrition 2015;113(2): 366-71. [DOI: 10.1017/S000711451400378X]

Kim 2006

Kim D, Kawachi I. Food taxation and pricing strategies to "thin out" the obesity epidemic. American Journal of Preventive Medicine 2006;30(5):430-7. [DOI: 10.1016/ j.amepre.2005.12.007]

\section{Kit 2013}

Kit BK, Fakhouri TH, Park S, Nielsen SJ, Ogden CL. Trends in sugar-sweetened beverage consumption among youth and adults in the United States: 1999-2010. American Journal of Clinical Nutrition 2013;98(1):180-8. [DOI: 10.3945/ajcn.112.057943]

Kodama 2012

Kodama S, Horikawa C, Fujihara K, Heianza Y, Hirasawa $\mathrm{R}$, Yachi $\mathrm{Y}$, et al. Comparisons of the strength of associations with future type 2 diabetes risk among anthropometric obesity indicators, including waist-to-height ratio: a metaanalysis. American Journal of Epidemiology 2012;176(11): 959-69. [DOI: 10.1093/aje/kws172]

\section{Lana 2015}

Lana A, Lopez-Garcia E, Rodriguez-Artalejo F. Consumption of soft drinks and health-related quality of life in the adult population. European Journal of Clinical Nutrition 2015;69(11):1226-32. [DOI: 10.1038/ ejcn.2015.103]

\section{Lasater 2011}

Lasater G, Piernas C, Popkin BM. Beverage patterns and trends among school-aged children in the US, 1989- 
2008. Nutrition Journal 2011;10:103. [DOI: 10.1186/ 1475-2891-10-103]

\section{Laviada-Molina 2016}

Laviada-Molina H, Molina-Seguí F, Arjona-Villicana RD, Morales-Gual M, Cuello-García CA, Pérez-Gaxiola G. Non-nutritive sweeteners for the prevention or treatment of being overweight or obesity. Cochrane Database of Systematic Reviews 2016, Issue 8. [DOI: 10.1002/ 14651858.CD012298; CD012298]

\section{Lhachimi 2013}

Lhachimi SK, Nusselder WJ, Lobstein TJ, Smit HA, Baili P, Bennett $\mathrm{K}$, et al. Modelling obesity outcomes: reducing obesity risk in adulthood may have greater impact than reducing obesity prevalence in childhood. Obesity Reviews 2013; Vol. 14, issue 7:523-31. [DOI: 10.1111/obr.12029]

Lhachimi 2016

Lhachimi SK, Pega F, Heise TL, Fenton C, Gartlehner $\mathrm{G}$, Griebler U, et al. Taxation of high saturated fat foods for reducing their consumption and preventing obesity or other adverse health outcomes. Manuscript submitted for publication 2016.

Lin 2011

Lin BH, Smith TA, Lee JY, Hall KD. Measuring weight outcomes for obesity intervention strategies: the case of a sugar-sweetened beverage tax. Economics and Human Biology 2011;9(4):329-41. [DOI: 10.1016/j.ehb.2011.08.007]

\section{Lorenc 2013}

Lorenc T, Petticrew M, Welch V, Tugwell P. What types of interventions generate inequalities? Evidence from systematic reviews. Journal of Epidemiology and Community Health 2013;67(2):190-3. [DOI: 10.1136/ jech-2012-201257]

\section{MacLean 2015}

MacLean PS, Higgins JA, Giles ED, Sherk VD, Jackman MR. The role for adipose tissue in weight regain after weight loss. Obesity Reviews 2015;16(Suppl 1):45-54. [DOI: 10.1111/obr.12255]

\section{Malik 2010}

Malik VS, Popkin BM, Bray GA, Despres JP, Willett WC, $\mathrm{Hu}$ FB. Sugar-sweetened beverages and risk of metabolic syndrome and type 2 diabetes: a meta-analysis. Diabetes Care 2010;33(11):2477-83. [DOI: 10.2337/dc10-1079]

\section{Malik 2013}

Malik VS, Pan A, Willett WC, Hu FB. Sugar-sweetened beverages and weight gain in children and adults: a systematic review and meta-analysis. American Journal of Clinical Nutrition 2013;98(4):1084-102. [DOI: 10.3945/ ajcn.113.058362]

\section{Maniadakis 2013}

Maniadakis N, Kapaki V, Damianidi L, Kourlaba G. A systematic review of the effectiveness of taxes on nonalcoholic beverages and high-in-fat foods as a means to prevent obesity trends. ClinicoEconomics and Outcomes Research 2013;5:519-43. [DOI: 10.2147/ceor.s49659]

\section{Marriott 2010}

Marriott BP, Olsho L, Hadden L, Connor P. Intake of added sugars and selected nutrients in the United States, National Health and Nutrition Examination Survey (NHANES) 2003-2006. Critical Reviews in Food Science and Nutrition 2010;50(3):228-58. [DOI: 10.1080/ $10408391003626223]$

\section{Mavoa 2008}

Mavoa HM, McCabe M. Sociocultural factors relating to Tongans' and Indigenous Fijians' patterns of eating, physical activity and body size. Asia Pacific Journal of Clinical Nutrition 2008;17(3):375-84. [PUBMED: 18818156]

\section{McDonald 2015}

McDonald A, Public Health Division, Secretariat of the Pacific Community. Sugar-sweetened beverage tax in Pacific Island countries and territories: a discussion paper. www.spc.int/images/publications/en/Divisions/Health/ sugar-sweetened-beverage-tax-in-PICTs-2.pdf (accessed 19 January 2016).

\section{McLaren 2007}

McLaren L. Socioeconomic status and obesity. Epidemiologic Reviews 2007;29:29-48. [DOI: 10.1093/epirev/mxm001]

Moher 2009

Moher D, Liberati A, Tetzlaff J, Altman DG, The PRISMA Group. Preferred Reporting Items for Systematic Reviews and Meta-Analyses: the PRISMA Statement. PLoS Medicine 2009;6(7):e1000097. [DOI: 10.1371/ journal.pmed.1000097]

Moynihan 2014

Moynihan PJ, Kelly SA. Effect on caries of restricting sugars intake: systematic review to inform WHO guidelines. Journal of Dental Research 2014;93(1):8-18. [DOI: 10.1177/0022034513508954]

Mytton 2012

Mytton OT, Clarke D, Rayner M. Taxing unhealthy food and drinks to improve health. BMJ 2012;344:e2931. [DOI: 10.1136/bmj.e2931]

Mytton 2014

Mytton OT, Eyles H, Ogilvie D. Evaluating the health impacts of food and beverage taxes. Current Obesity Reports 2014;3(4):432-9. [DOI: 10.1007/s13679-014-0123-x]

\section{National Board of Revenue Bangladesh 2014}

National Board of Revenue Bangladesh. Publications: VAT. www.nbr.gov.bd (accessed 19 January 2016).

\section{Nederkoorn 2011}

Nederkoorn C, Havermans RC, Giesen JC, Jansen A. High tax on high energy dense foods and its effects on the purchase of calories in a supermarket. An experiment. Appetite 2011; 56(3):760-5. [DOI: 10.1016/j.appet.2011.03.002]

\section{New York Times 1920}

City's soda cost millions monthly: tax on soft drinks in Manhattan and Bronx for February and March is $\$ 465$, 445. (New York Times; 23 May 1920). www.nytimes.com (accessed 19 January 2016). 
$\mathrm{Ng} 2014$

Ng M, Fleming T, Robinson M, Thomson B, Graetz N, Margono C. Global, regional, and national prevalence of overweight and obesity in children and adults during 1980-2013: a systematic analysis for the Global Burden of Disease Study 2013. Lancet 2014;384(9945):766-81. [DOI: 10.1016/S0140-6736(14)60460-8]

\section{NICE 2012}

NICE. Preventing obesity and helping people to manage their weight (last updated: 01 April 2015). publications.nice.org.uk/preventing-obesity-and-helpingpeople-to-manage-their-weight-lgb9. NICE, (accessed 10 April 2015).

\section{Niebylski 2015}

Niebylski ML, Redburn KA, Duhaney T, Campbell NR. Healthy food subsidies and unhealthy food taxation: a systematic review of the evidence. Nutrition 2015;31(6): 787-95. [DOI: 10.1016/j.nut.2014.12.010]

Northern Marianas Commonwealth Legislature 1995 Northern Marianas Commonwealth Legislature. Public law no. 9-57. www.cnmilaw.org/pdf/public laws/09/pl0957.pdf (accessed 19 January 2016).

\section{OECD 2014}

OECD. Revenue Statistics 2014. Vol. 1, Paris: OECD Publishing, 2014. [DOI: 10.1787/rev'stats-2014-en-fr]

\section{Ogden 2010}

Ogden CL, Lamb MM, Carroll MD, Flegal KM. Obesity and socioeconomic status in adults: United States, 20052008 (NCHS Data Brief). www.cdc.gov/nchs/data/ databriefs/db50.pdf (accessed 25 February 2015).

Ogilvie 2008

Ogilvie D, Fayter D, Petticrew M, Sowden A, Thomas $S$, Whitehead M, et al. The harvest plot: a method for synthesising evidence about the differential effects of interventions. BMC Medical Research Methodology 2008;8 (1):8. [DOI: $10.1186 / 1471-2288-8-8$ ]

\section{Palau Customs 2015}

Palau Customs 2015. Palau HS 2012. www.palaucustoms.org/files/common ' unit 'id/ bd748d15-e25c-4d6b-b972-ec097decea29/ Palau\%20HS\%202012.pdf (accessed 19 January 2016).

Pan 2011

Pan A, Hu FB. Effects of carbohydrates on satiety: differences between liquid and solid food. Current Opinion in Clinical Nutrition and Metabolic Care 2011;14(4): 385-90. [DOI: 10.1097/MCO.0b013e328346df36]

Pfinder 2016

Pfinder M, Katikireddi SV, Pega F, Gartlehner G, Fenton C, Griebler $\mathrm{U}$, et al. Taxation of unprocessed sugar or sugaradded foods for reducing their consumption and preventing obesity or other adverse health outcomes. Manuscript submitted for publication 2016

\section{Pigou 1932}

Pigou AC. The Economics of Welfare. 4th Edition. London: Macmillan, 1932.

\section{Popkin 2015}

Popkin BM, Hawkes C. Sweetening of the global diet, particularly beverages: patterns, trends, and policy responses. Lancet Diabetes \& Endocrinology 2015 Dec 1 [Epub ahead of print]. [DOI: 10.1016/s2213-8587 (15)00419-2]

\section{Poppitt 2015}

Poppitt S. Beverage consumption: are alcoholic and sugary drinks tipping the balance towards overweight and obesity?. Nutrients 2015;7(8):6700-18. [DOI: 10.3390/ nu7085304]

Powell 2009

Powell LM, Chriqui J, Chaloupka FJ. Associations between state-level soda taxes and adolescent body mass index. Journal of Adolescent Health 2009;45(3 Suppl):57-63. [DOI: 10.1016/j.jadohealth.2009.03.003]

Powell 2013

Powell LM, Chriqui JF, Khan T, Wada R, Chaloupka FJ. Assessing the potential effectiveness of food and beverage taxes and subsidies for improving public health: a systematic review of prices, demand and body weight outcomes. Obesity Reviews 2013;14(2):110-28. [DOI: 10.1111/ obr.12002]

Puhl 2009

Puhl RM, Heuer CA. The stigma of obesity: a review and update. Obesity 2009;17(5):941-64. [DOI: 10.1038/ oby.2008.636]

Qi 2012

Qi Q, Chu AY, Kang JH, Jensen MK, Curhan GC, Pasquale LR, et al. Sugar-sweetened beverages and genetic risk of obesity. New England Journal of Medicine 2012;367(15): 1387-96. [DOI: 10.1056/NEJMoa1203039]

Rahman 2010

Rahman M, Berenson AB. Accuracy of current body mass index obesity classification for white, black, and Hispanic reproductive-age women. Obstetrics and Gynecology 2010; 115(5):982-8. [DOI: 10.1097/AOG.0b013e3181da9423]

RevMan 2014 [Computer program] Nordic Cochrane Centre, The Cochrane Collaboration. Review Manager (RevMan). Version 5.3. Copenhagen: Nordic Cochrane Centre, The Cochrane Collaboration, 2014

Robroek 2013

Robroek SJ, Reeuwijk KG, Hillier FC, Bambra CL, van Rijn RM, Burdorf A. The contribution of overweight, obesity, and lack of physical activity to exit from paid employment: a meta-analysis. Scandinavian Journal of Work, Environment \& Health 2013;39(3):233-40. [DOI: 10.5271/sjweh.3354]

\section{Roqué i Figuls 2013}

Roqué i Figuls M, Martínez García L, Martinez-Zapata MJ, Pacheco R, Mauricio D, Bonfill Cosp X. Interventions for treating overweight or obesity in adults: an overview of systematic reviews. Cochrane Database of Systematic Reviews 2013, Issue 8. [DOI: 10.1002/14651858.CD010665] 
Rothman 2008

Rothman KJ. BMI-related errors in the measurement of obesity. International Journal of Obesity 2008;32(Suppl 3): 56-9. [DOI: 10.1038/ijo.2008.87]

\section{Roubenoff 1995}

Roubenoff R, Dallal GE, Wilson PW. Predicting body fatness: the body mass index vs estimation by bioelectrical impedance. American Journal of Public Health 1995;85(5): $726-8$.

Ryan 2016

Ryan R, Cochrane Consumers and Communication Review Group. Cochrane Consumers and Communication Review Group: data synthesis and analysis. cccrg.cochrane.org/sites/cccrg.cochrane.org/files/uploads/

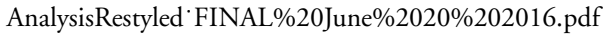
(accessed 22 July 2016).

\section{Salois 2012}

Salois MJ. Obesity and diabetes, the built environment, and the 'local' food economy in the United States, 2007. Economics \& Human Biology 2012;10(1):35-42. [DOI: 10.1016/j.ehb.2011.04.001]

\section{Sassi 2014}

Sassi F, Belloni A. Fiscal incentives, behavior change and health promotion: what place in the health-in-all-policies toolkit?. Health Promotion International 2014;29(Suppl 1): $103-12$.

Scott-Thomas 2013

Scott-Thomas C. Denmark to scrap decades-old soft drink tax. www.foodnavigator.com/Policy/Denmark-to-scrapdecades-old-soft-drink-tax (accessed 19 January 2016).

\section{Service Public 2016}

Service Public. Contributions on sugar added-, sweetenedor caffeinated drinks [Contributions sur les boissons sucrées, édulcorées ou contenant de la caféine]. www.servicepublic.fr/professionnels-entreprises/vosdroits/F31871 (accessed 19 January 2016).

Servicio de Impuestos Internos Chile 2014 Servicio de Impuestos Internos Chile. CIRCULAR N ${ }^{\circ}$ 51. www.sii.cl/documentos/circulares/2014/circu51.pdf (accessed 19 January 2016).

\section{Sharma 2014}

Sharma A, Hauck K, Hollingsworth B, Siciliani L. The effects of taxing sugar-sweetened beverages across different income groups. Health Economics 2014;23(9):1159-84. [DOI: 10.1002/hec.3070]

\section{Sheiham 2014}

Sheiham A, James WP. A reappraisal of the quantitative relationship between sugar intake and dental caries: the need for new criteria for developing goals for sugar intake. BMC Public Health 2014;14:863. [DOI: 10.1186/ 1471-2458-14-863]

\section{Shemilt 2015}

Shemilt I, Marteau TM, Smith RD, Ogilvie D. Use and cumulation of evidence from modelling studies to inform policy on food taxes and subsidies: biting off more than we can chew?. BMC Public Health 2015;15:297. [DOI: 10.1186/s12889-015-1641-5]

Simon 2006

Simon GE, Von Korff M, Saunders K, Miglioretti DL, Crane PK, van Belle G, et al. Association between obesity and psychiatric disorders in the US adult population. Archives of General Psychiatry 2006;63(7):824-30. [DOI: 10.1001/archpsyc.63.7.824]

\section{Singh 2015a}

Singh GM, Micha R, Khatibzadeh S, Shi P, Lim S, Andrews $\mathrm{KG}$, et al. Global, regional, and national consumption of sugar-sweetened beverages, fruit juices, and milk: a systematic assessment of beverage intake in 187 countries. PLoS ONE 2015;10(8):e0124845. [DOI: 10.1371/ journal.pone.0124845]

\section{Singh 2015b}

Singh GM, Micha R, Khatibzadeh S, Lim S, Ezzati M, Mozaffarian D. Estimated global, regional, and national disease burdens related to sugar-sweetened beverage consumption in 2010. Circulation (in press). [DOI: 10.1161/circulationaha.114.010636]

\section{Slining 2013}

Slining MM, Popkin BM. Trends in intakes and sources of solid fats and added sugars among U.S. children and adolescents: 1994-2010. Pediatric Obesity 2013;8(4): 307-24. [DOI: 10.1111/j.2047-6310.2013.00156.x]

\section{Snowdon 2014}

Snowdon W. Sugar-sweetened beverages in Pacific Island countries and territories: problems and solutions?. Pacific Health Dialogue 2014;20(1):43-6.

\section{Stern 2014}

Stern D, Piernas C, Barquera S, Rivera JA, Popkin BM. Caloric beverages were major sources of energy among children and adults in Mexico, 1999-2012. Journal of Nutrition 2014;144(6):949-56. [DOI: 10.3945/ jn.114.190652]

Strnad 2004

Strnad J. Conceptualizing the 'Fat Tax': the role of food taxes in developed economies. Stanford Law and Economics Working Paper No. 286; 2010 (accessed 16 June 2015). [DOI: $10.2139 /$ ssrn. 561321]

\section{Sturm 2014}

Sturm R, An R. Obesity and economic environments. CA: A Cancer Journal for Clinicians 2014;64(5):337-50. [DOI: $10.3322 /$ caac.21237]

\section{Swinburn 2015}

Swinburn B, Kraak V, Rutter H, Vandevijvere S, Lobstein T, Sacks G, et al. Strengthening of accountability systems to create healthy food environments and reduce global obesity. Lancet 2015;385(9986):2534-45. [DOI: 10.1016/ S0140-6736(14)61747-5]

\section{Te Morenga 2013}

Te Morenga L, Mallard S, Mann J. Dietary sugars and body weight: systematic review and meta-analyses of randomised 
controlled trials and cohort studies. BMJ 2013;346:e7492. [DOI: 10.1136/bmj.e7492]

\section{Thomson 2013}

Thomson HJ, Thomas S. The effect direction plot: visual display of non-standardised effects across multiple outcome domains. Research Synthesis Methods 2013;4(1):95-101. [DOI: 10.1002/jrsm.1060]

Thow 2011

Thow AM, Quested C, Juventin L, Kun R, Khan AN, Swinburn B. Taxing soft drinks in the Pacific: implementation lessons for improving health. Health Promotion International 2011;26(1):55-64. [DOI: 10.1093/heapro/daq057]

Thow 2014

Thow AM, Downs S, Jan S. A systematic review of the effectiveness of food taxes and subsidies to improve diets: understanding the recent evidence. Nutrition Reviews 2014; 72(9):551-65. [DOI: 10.1111/nure.12123]

Tsai 2011

Tsai AG, Williamson DF, Glick HA. Direct medical cost of overweight and obesity in the United States: a quantitative systematic review. Obesity Reviews 2011;12(1):50-61. [DOI: 10.1111/j.1467-789X.2009.00708.x]

Turley 2013

Turley R, Saith R, Bhan N, Rehfuess E, Carter B. Slum upgrading strategies involving physical environment and infrastructure interventions and their effects on health and socio-economic outcomes. Cochrane Database of Systematic Reviews 2013, Issue 1. [DOI: 10.1002/ 14651858.CD010067.pub2]

\section{Ul-Haq 2013}

Ul-Haq Z, Mackay DF, Fenwick E, Pell JP. Meta-analysis of the association between body mass index and healthrelated quality of life among children and adolescents, assessed using the pediatric quality of life inventory index. Journal of Pediatrics 2013;162(2):280-6. [DOI: 10.1016/ j.jpeds.2012.07.049]

\section{Valera 2015}

Valera B, Sohani Z, Rana A, Poirier P, Anand SS. The ethnoepidemiology of obesity. Canadian Journal of Cardiology 2015;31(2):131-41.

\section{Van Nuys 2014}

Van Nuys K, Globe D, Ng-Mak D, Cheung H, Sullivan J, Goldman D. The association between employee obesity and employer costs: evidence from a panel of U.S. employers. American Journal of Health Promotion 2014;28(5):277-85. [DOI: 10.4278/ajhp.120905-QUAN-428]

von Philipsborn 2016

von Philipsborn P, Stratil JM, Burns J, Busert LK, Pfadenhauer LM, Polus S, et al. Environmental interventions to reduce the consumption of sugar-sweetened beverages and their effects on health. Cochrane Database of Systematic Reviews 2016, Issue 7. [DOI: 10.1002/ 14651858.CD012292; CD012292]

\section{Walker 2014}

Walker RW, Dumke KA, Goran MI. Fructose content in popular beverages made with and without high-fructose corn syrup. Nutrition 2014;30(7-8):928-35. [DOI: 10.1016/j.nut.2014.04.003]

\section{Wang 2012}

Wang Y, Lim H. The global childhood obesity epidemic and the association between socio-economic status and childhood obesity. International Review of Psychiatry 2012; 24(3):176-88. [DOI: 10.3109/09540261.2012.688195]

\section{Wansink 2014}

Wansink B, Hanks AS, Cawley J, Just DR. From Coke to Coors: a field study of a fat tax and its unintended consequences (2014). ssrn.com/abstract $=2473623$. Cornell University: Cornell University, (accessed 30 June 2015).

\section{Waterlander 2014}

Waterlander WE, Ni Mhurchu C, Steenhuis IH. Effects of a price increase on purchases of sugar sweetened beverages. Results from a randomized controlled trial. Appetite 2014; 78:32-9. [DOI: 10.1016/j.appet.2014.03.012]

\section{Weinsier 1998}

Weinsier RL, Hunter GR, Heini AF, Goran MI, Sell SM. The etiology of obesity: relative contribution of metabolic factors, diet, and physical activity. American Journal of Medicine 1998;105(2):145-50.

\section{WHO 2000}

WHO. Obesity: preventing and managing the global epidemic. Report of a WHO consultation. World Health Organization Technical Report Series 2000; Vol. 894.

\section{WHO 2003}

WHO. Diet, nutrition, and the prevention of chronic diseases. Geneva: World Health Organization, 2003.

\section{WHO 2009}

WHO. Global health risks. Geneva: World Health Organization, 2009.

\section{WHO 2011}

WHO. International statistical classification of diseases and related health problems. Geneva: World Health Organization, 2011.

\section{WHO 2013}

WHO. Global action plan for the prevention and control of noncommunicable diseases 2013-2020. www.who.int/iris/ bitstream $/ 10665 / 94384 / 1 / 97892415062366^{\circ}$ eng.pdf?ua $=1$ (accessed 30 June 2015).

WHO 2014

WHO. Global status report on noncommunicable diseases 2014. Geneva: World Health Organization, 2014.

\section{WHO 2015}

WHO. Guideline: sugars intake for adult and children. Geneva: World Health Organization, 2015.

\section{Withrow 2011}

Withrow D, Alter DA. The economic burden of obesity worldwide: a systematic review of the direct costs of obesity. 
Wong MS, Nau C, Kharmats AY, Vedovato GM, Cheskin LJ, Gittelsohn J, et al. Using a computational model to quantify the potential impact of changing the placement of healthy beverages in stores as an intervention to "nudge" adolescent behavior choice. BMC Public Health 2015;15: 1284. [DOI: 10.1186/s12889-015-2626-0]

\section{Woodward-Lopez 2011}

Woodward-Lopez G, Kao J, Ritchie L. To what extent have sweetened beverages contributed to the obesity epidemic?

. Public Health Nutrition 2011;14(3):499-509. [DOI:

Yang CC, Chiou WB. Substitution of healthy for unhealthy beverages among college students. A health-concerns and behavioral-economics perspective. Appetite 2010;54(3): 512-6. [DOI: 10.1016/j.appet.2010.02.004]

Zheng 2015

Zheng M, Allman-Farinelli M, Heitmann BL, Rangan A. Substitution of sugar-sweetened beverages with other beverage alternatives: a review of long-term health outcomes. Journal of the Academy of Nutrition and Dietetics 2015;115(5):767-79. [DOI: 10.1016/j.jand.2015.01.006]

* Indicates the major publication for the study

\section{ADDITIONAL TABLES}

Table 1. Examples of implemented SSB taxes

\begin{tabular}{|c|c|c|c|}
\hline Country & $\begin{array}{l}\text { Year of implementation (Year } \\
\text { of last modification/informa- } \\
\text { tion) }\end{array}$ & Description of tax & References \\
\hline American Samoa & 1963 (n/a) & $\begin{array}{l}\text { General description: } \\
\text { Import duty and excise tax on } \\
\text { carbonated beverages } \\
\text { Tax rate: } \\
\text { USD } 0.15 \text { per } 12 \text { fluid ounces } \\
\text { or fraction thereof } \\
\text { Taxed SSB products: } \\
\text { Soft drinks, non-alcoholic car- } \\
\text { bonated beverages, and syrups } \\
\text { for SSB preparation } \\
\text { Notable exemptions: } \\
\text { n/a }\end{array}$ & $\begin{array}{l}\text { (American Samoa Bar } \\
\text { Association 2015) }\end{array}$ \\
\hline Australia & $2000(2012)$ & $\begin{array}{l}\text { General description: } \\
\text { Goods and services tax (GST) } \\
\text { on } \\
\text { various (food-)products (SSBs, } \\
\text { bakery products, ice cream etc. } \\
\text { ) and other services } \\
\text { Tax rate: } \\
10 \% \text { on goods consumed in } \\
\text { Australia } \\
\text { Taxed SSB products: } \\
\text { Soft drinks and flavoured milk } \\
\text { (e.g. chocolate milk) } \\
\text { Notable exemptions: } \\
\text { Fruit juices (at least containing } \\
90 \% \text { by volume of juice), bot- } \\
\text { tled drinking water, tea or cof- }\end{array}$ & $\begin{array}{l}\text { (Australian Taxation Office } \\
\text { 2012) }\end{array}$ \\
\hline
\end{tabular}


Table 1. Examples of implemented SSB taxes (Continued)

fee (non-'ready to drink'), and

milk

Barbados

Barbados
2015 (2015)

\section{General description:}

Excise tax on sweetened beverages; prior to application of VAT

Tax rate:

$10 \%$; results in an after-VAT price increase of $11.75 \%$ for imported and locally produced drinks

Taxed SSB products:

Carbonated soft drinks, sports drinks, and sweetened juices

Notable exemptions:

Fruit juices (containing 100\% natural sugars), coconut water, and milk

\begin{tabular}{|c|c|c|}
\hline Bangladesh & 2014 (2014) & $\begin{array}{l}\text { General description: } \\
\text { Supplementary duty on soft } \\
\text { drinks levied at manufacturing } \\
\text { stage } \\
\text { Tax rate: } \\
25 \% \\
\text { Taxed SSB products: } \\
\text { Soft drinks; energy drinks } \\
\text { Notable exemptions: } \\
\text { n/a }\end{array}$ \\
\hline Chile & $2015(2015)$ & $\begin{array}{l}\text { General description: } \\
\text { Ad valorem tax on soft drinks } \\
\text { Tax rate: } \\
18 \% \text { on soft drinks high-in- } \\
\text { sugar; } 10 \% \text { on flavoured wa- } \\
\text { ter, sport drinks etc. with lower } \\
\text { sugar content } \\
\text { Taxed SSB products: } \\
\text { Highest tax rate on soft drink } \\
\text { products with high sugar con- } \\
\text { tent (sugar content }>15 \text { grams } \\
\text { per } 240 \text { ml; } 6.25 \text { grams per } 100 \\
\text { ml); lower tax rates on flavoured } \\
\text { water, and sport drinks etc. with } \\
\text { lower sugar content } \\
\text { Notable exemptions: } \\
\text { n/a }\end{array}$ \\
\hline
\end{tabular}

(Ernst \& Young 2015)

(National Board of Revenue

Bangladesh 2014)

(Servicio de Impuestos Internos

Chile 2014) 
Table 1. Examples of implemented SSB taxes (Continued)

\begin{tabular}{|c|c|c|c|}
\hline Cook Islands & $\mathrm{n} / \mathrm{a}(2014)$ & $\begin{array}{l}\text { General description: } \\
\text { Tax on sugar-added drinks } \\
\text { Tax rate: } \\
\text { NZD } 9.80 \text { per kg of sugar in } \\
\text { soft drinks } \\
\text { Taxed SSB products: } \\
\text { Beverages containing added } \\
\text { sugar or other sweetening mat- } \\
\text { ter or flavoured } \\
\text { Notable exemptions: } \\
\text { Non-sugar-added waters, in- } \\
\text { cluding natural or artificial } \\
\text { mineral waters }\end{array}$ & (McDonald 2015) \\
\hline Denmark & 1930s (2014: removed) & $\begin{array}{l}\text { General description: } \\
\text { Excise tax on soft drinks } \\
\text { Tax rate: } \\
\text { DKK } 1.64 \text { per litre on SSBs } \\
\text { Taxed SSB products: } \\
\text { Soft drinks } \\
\text { Notable exemptions: } \\
\text { n/a }\end{array}$ & (Scott-Thomas 2013) \\
\hline Dominica & $2015(2015)$ & $\begin{array}{l}\text { General description: } \\
\text { Excise tax on soft drinks and en- } \\
\text { ergy drinks } \\
\text { Tax rate: } \\
\text { XCD } 0.20 \text { per litre on soft } \\
\text { drinks; } 10 \% \text { on energy drinks } \\
\text { Taxed SSB products: } \\
\text { Soft drinks and energy drinks } \\
\text { Notable exemptions: } \\
\text { n/a }\end{array}$ & $\begin{array}{l}\text { (Government of Dominica } \\
\text { 2015) }\end{array}$ \\
\hline $\begin{array}{l}\text { Federated States of } \\
\text { Micronesia }\end{array}$ & $2004(\mathrm{n} / \mathrm{a})$ & $\begin{array}{l}\text { General description: } \\
\text { Import duty on sugar-added } \\
\text { drinks } \\
\text { Tax rate: } \\
25 \% \\
\text { Taxed SSB products: } \\
\text { Soft drinks, preparation prod- } \\
\text { ucts for soft drinks } \\
\text { Notable exemptions: } \\
\text { n/a }\end{array}$ & (McDonald 2015) \\
\hline Finland & $1940(2014)$ & $\begin{array}{l}\text { General description: } \\
\text { Excise tax on sugar-added } \\
\text { drinks, non-alcoholic drinks, } \\
\text { sweets, and ice-cream }\end{array}$ & (Ecorys 2014) \\
\hline
\end{tabular}

Taxation of sugar-sweetened beverages for reducing their consumption and preventing obesity or other adverse health outcomes 
Table 1. Examples of implemented SSB taxes (Continued)

\begin{tabular}{|c|c|c|c|}
\hline & & $\begin{array}{l}\text { Tax rate: } \\
\text { EUR } 0.220 \text { per litre on bever- } \\
\text { ages with more than } 0.5 \% \text { sugar } \\
\text { Taxed SSB products: } \\
\text { Beverages containing more } \\
\text { than } 0.5 \% \text { sugar } \\
\text { Notable exemptions: } \\
\text { Water, milk }\end{array}$ & \\
\hline Fiji & $2011(\mathrm{n} / \mathrm{a})$ & $\begin{array}{l}\text { General description: } \\
\text { Import duty on sugar-added } \\
\text { drinks and various other food } \\
\text { products } \\
\text { Tax rate: } \\
32 \% \\
\text { Taxed SSB products: } \\
\text { Soft drinks and various other } \\
\text { food products (e.g. bottled wa- } \\
\text { ter) } \\
\text { Notable exemptions: } \\
\text { n/a }\end{array}$ & (McDonald 2015) \\
\hline France & $2012(2016)$ & $\begin{array}{l}\text { General description: } \\
\text { Excise tax on beverages with } \\
\text { added sugar or sweeteners } \\
\text { levied on producers, importer } \\
\text { or merchants } \\
\text { Tax rate: } \\
\text { EUR 7.16 per hectolitre (2012) } \\
\text {, EUR } 7.53 \text { per hectolitre } \\
\text { (2016) of the product } \\
\text { Taxed SSB products: } \\
\text { Beverages with added sugar or } \\
\text { sweeteners regardless the quan- } \\
\text { tity of sugar } \\
\text { Notable exemptions: } \\
\text { Milk, } \\
\text { sugar-added drinks for medical } \\
\text { treatment; drinks based on tea, } \\
\text { coffee consumed in cups and } \\
\text { glasses at restaurants }\end{array}$ & $\begin{array}{l}\text { (Ecorys 2014; Service Public } \\
\text { 2016) }\end{array}$ \\
\hline
\end{tabular}

\section{General description:}

Import duty and excise tax on sweetened drinks and various other food products

Tax rate:

XPF 40 per litre on locally produced sweetened drinks; XPF 
Table 1. Examples of implemented SSB taxes (Continued)

\begin{tabular}{|c|c|c|c|}
\hline & & $\begin{array}{l}60 \text { per litre on imported sweet- } \\
\text { ened drinks } \\
\text { Taxed SSB products: } \\
\text { Sweetened drinks } \\
\text { Notable exemptions: } \\
\text { n/a }\end{array}$ & \\
\hline Hungary & $2011(2013)$ & $\begin{array}{l}\text { General description: } \\
\text { Specific product tax on soft } \\
\text { drinks, syrups/concentrates and } \\
\text { various other food products } \\
\text { Tax rate: } \\
\text { HUF } 7 \text { per litre on soft drink } \\
\text { products; HUF } 200 \text { per litre on } \\
\text { syrups/concentrates products } \\
\text { Taxed SSB products: } \\
\text { Soft drinks; syrups/concen- } \\
\text { trates for soft drink preparation } \\
\text { high in sugar (sugar content }>8 \\
\text { grams per } 100 \text { ml) } \\
\text { Notable exemptions: } \\
\text { Beverages with fruit or veg- } \\
\text { etable content }>25 \% \text {; beverages } \\
\text { based on raw milk content }> \\
50 \% \text {; special syrups }\end{array}$ & (Ecorys 2014) \\
\hline Kiribati & $2014(2014)$ & $\begin{array}{l}\text { General description: } \\
\text { Excise tax on beverages contain- } \\
\text { ing added sugars or other sweet- } \\
\text { ening matters } \\
\text { Tax rate: } \\
40 \% \\
\text { Taxed SSB products: } \\
\text { Beverages containing added } \\
\text { sugars or other sweetening mat- } \\
\text { ters } \\
\text { Notable exemptions: } \\
\text { Unknown }\end{array}$ & (McDonald 2015) \\
\hline Mauritius & $2013(2014)$ & $\begin{array}{l}\text { General description: } \\
\text { Excise tax on carbonated bever- } \\
\text { ages, fruit juice and syrup } \\
\text { Tax rate: } \\
\text { MUR } 0.03 \text { per gram of sugar } \\
\text { Taxed SSB products: } \\
\text { Excise tax on carbonated bever- } \\
\text { ages, fruit juices and syrups } \\
\text { Notable exemptions: } \\
\text { n/a }\end{array}$ & $\begin{array}{l}\text { (Government of Mauritius } \\
\text { 2015) }\end{array}$ \\
\hline
\end{tabular}


Table 1. Examples of implemented SSB taxes (Continued)

\begin{tabular}{|c|c|c|c|}
\hline Mexico & $2014(2014)$ & $\begin{array}{l}\text { General description: } \\
\text { Excise tax on non-dairy and } \\
\text { non-alcoholic beverages with } \\
\text { added sugar; accompanied by } \\
\text { an ad valorem tax on high en- } \\
\text { ergy dense food } \\
\text { Tax rate: } \\
\text { MXN } 1 \text { per litre on SSBs; ap- } \\
\text { plies to the largest typical vol- } \\
\text { ume possible utilising caloric } \\
\text { sweeteners or concentrate as } \\
\text { well } \\
\text { Taxed SSB products: } \\
\text { Sodas, juices, nectars, fruit con- } \\
\text { centrates, drink mix powder } \\
\text { Notable exemptions: } \\
\text { Dairy products, non-caloric } \\
\text { beverages }\end{array}$ & (Colchero 2016) \\
\hline Nauru & 2007 (2010) & $\begin{array}{l}\text { General description: } \\
\text { Import duty on sugar and prod- } \\
\text { ucts containing added sugars } \\
\text { Tax rate: } \\
30 \% \text { of value } \\
\text { Taxed SSB products: } \\
\text { Sugar and products containing } \\
\text { added sugars } \\
\text { Notable exemptions: } \\
\text { Water }\end{array}$ & $\begin{array}{l}\text { (Government of the Republic } \\
\text { of Nauru 2010) }\end{array}$ \\
\hline Norway & $\mathrm{n} / \mathrm{a}(2016)$ & $\begin{array}{l}\text { General description: } \\
\text { Excise tax on sugar and sugar- } \\
\text { added products } \\
\text { Tax rate: } \\
\text { NOK } 7.66 \text { per kg of sugar } \\
\text { Taxed SSB products: } \\
\text { Refined sugar or food products } \\
\text { containing added refined sugar } \\
\text { Notable exemptions: } \\
\text { n/a }\end{array}$ & (Government of Norway 2015) \\
\hline Northern Mariana Islands & $1979(1995)$ & $\begin{array}{l}\text { General description: } \\
\text { Excise tax on soft drinks } \\
\text { Tax rate: } \\
\text { USD } 0.005 \text { per fluid ounce or } \\
\text { fractional equivalent thereof } \\
\text { Taxed SSB products: } \\
\text { Soft drinks (carbonated or non- } \\
\text { carbonated or non-alcoholic }\end{array}$ & $\begin{array}{l}\text { (Northern } \quad \text { Marianas } \\
\text { Commonwealth Legislature } \\
\text { 1995) }\end{array}$ \\
\hline
\end{tabular}

Taxation of sugar-sweetened beverages for reducing their consumption and preventing obesity or other adverse health outcomes 
Table 1. Examples of implemented SSB taxes (Continued)

\begin{tabular}{|c|c|c|c|}
\hline & & $\begin{array}{l}\text { beverages) } \\
\text { Notable exemptions: } \\
\text { Drinkable dairy products, fruit } \\
\text { juices, vegetable juices, bottled } \\
\text { drinking water, tea or tea prod- } \\
\text { ucts, concentrates }\end{array}$ & \\
\hline Palau & $\mathrm{n} / \mathrm{a}(2015)$ & $\begin{array}{l}\text { General description: } \\
\text { Import duty on drinks contain- } \\
\text { ing added sugar or other sweet- } \\
\text { ening matter } \\
\text { Tax rate: } \\
\text { USD } 0.28175 \text { per litre } \\
\text { Taxed SSB products: } \\
\text { Drinks containing added sugar } \\
\text { or other sweetening matter } \\
\text { Notable exemptions: } \\
\text { Water, fruit juices, vegetable } \\
\text { juices }\end{array}$ & (Palau Customs 2015) \\
\hline Republic of Marshall Islands & $2004(\mathrm{n} / \mathrm{a})$ & $\begin{array}{l}\text { General description: } \\
\text { Import duty on carbonated } \\
\text { beverages } \\
\text { Tax rate: } \\
\text { USD } 0.01666 \text { per ounce on } \\
\text { carbonated beverages } \\
\text { Taxed SSB products: } \\
\text { Carbonated beverages } \\
\text { Notable exemptions: } \\
\text { n/a }\end{array}$ & (McDonald 2015) \\
\hline Samoa & 1984 & $\begin{array}{l}\text { General description: } \\
\text { Import duty and excise tax on } \\
\text { carbonated beverages } \\
\text { Tax rate: } \\
\text { WST } 0.40 \text { per litre on carbon- } \\
\text { ated beverages } \\
\text { Taxed SSB products: } \\
\text { Carbonated beverages } \\
\text { Notable exemptions: } \\
\text { n/a }\end{array}$ & (McDonald 2015; Thow 2011) \\
\hline St Helena & $2014(2014)$ & $\begin{array}{l}\text { General description: } \\
\text { Excise tax on carbonated bever- } \\
\text { ages } \\
\text { Tax rate: } \\
\text { SHP } 0.75 \text { per litre on carbon- } \\
\text { ated beverages } \\
\text { Taxed SSB products: }\end{array}$ & $\begin{array}{l}\text { (Government of St Helena } \\
\text { 2013) }\end{array}$ \\
\hline
\end{tabular}


Table 1. Examples of implemented SSB taxes (Continued)

\begin{tabular}{|c|c|c|c|}
\hline & & $\begin{array}{l}\text { Carbonated beverages contain- } \\
\text { ing at least } 15 \text { grams sugar per } \\
\text { litre } \\
\text { Notable exemptions: } \\
\text { n/a }\end{array}$ & \\
\hline Tonga & $2013(2013)$ & $\begin{array}{l}\text { General description: } \\
\text { Excise tax on carbonated bever- } \\
\text { ages } \\
\text { Tax rate: } \\
\text { TOP } 1 \text { per litre on carbonated } \\
\text { beverages } \\
\text { Taxed SSB products: } \\
\text { Carbonated beverages } \\
\text { Notable exemptions: } \\
\text { n/a }\end{array}$ & (McDonald 2015) \\
\hline Vanuatu & $2014(2014)$ & $\begin{array}{l}\text { General description: } \\
\text { Excise tax on beverages contain- } \\
\text { ing added sugars or other sweet- } \\
\text { ening matters } \\
\text { Tax rate: } \\
\text { VUV } 50 \text { per litre on carbonated } \\
\text { beverages } \\
\text { Taxed SSB products: } \\
\text { Carbonated beverages } \\
\text { Notable exemptions: } \\
\text { n/a }\end{array}$ & (Government of Vanuatu 2015) \\
\hline United States & $1920(2015)$ & $\begin{array}{l}\text { General description: } \\
\text { Various statewide or citywide } \\
\text { taxes on beverages containing } \\
\text { added sugars or syrups/drink- } \\
\text { ing powder/concentrates } \\
\text { Tax rate: } \\
0 \% \text { to } 7 \% \text { on various SSB prod- } \\
\text { ucts } \\
\text { Taxed SSB products: } \\
\text { Beverages containing added } \\
\text { sugars or syrups/drinking pow- } \\
\text { der/concentrates } \\
\text { Notable exemptions: } \\
\text { Various }\end{array}$ & $\begin{array}{l}\text { (Chriqui 2014; City of Berkeley } \\
\text { 2014; City of Philadelphia } \\
\text { 2016; New York Times 1920) }\end{array}$ \\
\hline $\begin{array}{l}\text { United States } \\
\text { (Example: City of Berkeley, } \\
\text { California) }\end{array}$ & $2015(2015)$ & $\begin{array}{l}\text { General description: } \\
\text { Excise tax on SSBs and caloric } \\
\text { sweeteners } \\
\text { Tax rate: } \\
\text { USD } 0.01 \text { per fluid ounce on } \\
\text { SSB products; applies to the }\end{array}$ & (City of Berkeley 2014) \\
\hline
\end{tabular}

Taxation of sugar-sweetened beverages for reducing their consumption and preventing obesity or other adverse health outcomes 
Table 1. Examples of implemented SSB taxes (Continued)

\begin{tabular}{|c|c|c|c|}
\hline & & $\begin{array}{l}\text { largest typical volume possible } \\
\text { utilising caloric sweeteners as } \\
\text { well } \\
\text { Taxed SSB products: } \\
\text { SSBs and added caloric sweet- } \\
\text { eners } \\
\text { Notable exemptions: } \\
\text { Natural or common sweeteners, } \\
\text { fruit and vegetable concentrate } \\
\text { or juice ( } 100 \%) \text {, milk, bever- } \\
\text { ages for medical use or weight } \\
\text { reduction, beverage products } \\
\text { for 'babies' }\end{array}$ & \\
\hline $\begin{array}{l}\text { United States } \\
\text { (Example: City of Philadelphia, } \\
\text { Pennsylvania) }\end{array}$ & 2017 (2016) & $\begin{array}{l}\text { General description: } \\
\text { Excise tax on SSBs and caloric } \\
\text { sweeteners } \\
\text { Tax rate: } \\
\text { USD } 0.015 \text { per fluid ounce on } \\
\text { SSB products, including artifi- } \\
\text { cial sweeteners; syrup or other } \\
\text { concentrates: USD } 0.015 \text { per } \\
\text { fluid ounce on the resulting } \\
\text { beverage, prepared to the man- } \\
\text { ufacturer's specifications } \\
\text { Taxed SSB products: } \\
\text { SSBs and added caloric sweet- } \\
\text { eners } \\
\text { Notable exemptions: } \\
\text { Beverage products for 'babies', } \\
\text { medical food, milk products } \\
\text { (volume of milk } \geq 50 \% \text { ), fruit } \\
\text { and vegetable products (volume } \\
\geq 50 \% \text { ) }\end{array}$ & (City of Philadelphia 2016) \\
\hline
\end{tabular}

Additional taxes on cans, bottles, and containers as well as not yet fully implemented SSB taxes (e.g. Philippines, UK) are not reported. This also applies for countries with no specific tax differences between bottled water and SSBs.

Table 2. Advisory group members

\begin{tabular}{ll}
\hline Name & Occupation \\
\hline Cristina Cleghorn & Department of Public Health, University of Otago, Wellington, NZ \\
\hline Emilia Crighton & Faculty of Public Health, London, UK \\
\hline
\end{tabular}

Peter Faassen de Heer CMO and Public Health Directorate, Scottish Government, Edinburgh, UK 
Table 2. Advisory group members (Continued)

\begin{tabular}{ll}
\hline Torben Jørgensen & Professor, Department of Public Health, University of Copenhagen, Copenhagen, Denmark \\
\hline Dionne Mackison & Department for International Development, UK Government, Glasgow, UK \\
\hline Barry Popkin & Professor of Global Nutrition, University of North Carolina, Chapel Hill, US \\
\hline
\end{tabular}

Table 3. Feedback advisory group (online survey)

\begin{tabular}{|c|c|c|}
\hline & \multicolumn{2}{|c|}{$\begin{array}{l}\text { 1.1. Rank outcomes according to their relative importance for the scope of the } \\
\text { reviews and general public health decision-making in the context of food taxation; } \\
\text { 9-point Likert scale (categories: } 1 \text { to } 3 \text { - of limited importance; } 4 \text { to } 6 \text {-important; } \\
7 \text { to } 9 \text { - critical) }\end{array}$} \\
\hline Outcomes: & Average score: & Rank: \\
\hline prevalence of overweight & 7.67 & 3 \\
\hline prevalence of obesity & 7.67 & 3 \\
\hline incidence of overweight & 8.00 & 1 \\
\hline incidence of obesity & 8.00 & 1 \\
\hline $\begin{array}{l}\text { caloric intake through SSBs or sugar/sugar- } \\
\text { added food }\end{array}$ & 7.33 & 8 \\
\hline total calorie consumption & 6.67 & 11 \\
\hline $\begin{array}{l}\text { consumption of SSBs or sugar/sugar-added } \\
\text { food (e.g. frequency, amount) }\end{array}$ & 7.33 & 8 \\
\hline health-related quality of life & 4.00 & 16 \\
\hline $\begin{array}{l}\text { total sales of SSBs or sugar/sugar-added } \\
\text { food }\end{array}$ & 5.33 & 15 \\
\hline composition of diet (e.g. fat, sugar, salt) & 6.67 & 11 \\
\hline total expenditures on food & 4.00 & 16 \\
\hline $\begin{array}{l}\text { total expenditures on SSBs or sugar/sugar- } \\
\text { added food (e.g. frequency, amount) }\end{array}$ & 5.67 & 14 \\
\hline $\begin{array}{l}\text { any health outcomes or health-related un- } \\
\text { intended consequences }\end{array}$ & 7.67 & 3 \\
\hline
\end{tabular}

Taxation of sugar-sweetened beverages for reducing their consumption and preventing obesity or other adverse health outcomes 
Table 3. Feedback advisory group (online survey) (Continued)

\begin{tabular}{l|l|l}
\hline e.g. mortality & 7.00 & 10 \\
\hline e.g. dental caries & 6.00 & 13 \\
\hline e.g. diabetes & 7.67 & 3 \\
\hline e.g. CVD & 7.67 & 3 \\
\hline
\end{tabular}

2.1. How well do the presented outcomes cover the basic review scope?

\begin{tabular}{|c|c|c|}
\hline Answers: & Rating: & Number of responses: \\
\hline Important outcomes are presented & $66.67 \%$ & 2 \\
\hline Important outcomes are missing & $33.33 \%$ & 1 \\
\hline Comments (1): & \multicolumn{2}{|c|}{$\begin{array}{l}\text { I imagine some evidence will be presented as simply a change in BMI or other markers } \\
\text { of obesity rather than a change in incidence or prevalence of obesity (Cristina Cleghorn) }\end{array}$} \\
\hline
\end{tabular}

3.1. Do you think the same outcomes are appropriate for both reviews (SSB; sugar or sugar-added foods)?

\begin{tabular}{l|l|l}
\hline Answers: & Rating: & Number of responses: \\
\hline $\begin{array}{l}\text { The same group of outcomes should be } \\
\text { utilised in both reviews }\end{array}$ & $66.67 \%$ & 2 \\
\hline $\begin{array}{l}\text { Different outcomes should be utilised in } \\
\text { the two reviews }\end{array}$ & $33.33 \%$ & 1 \\
\hline Comments (1): & $\begin{array}{l}\text { Foods study: Hard to go beyond kcal and weight and minimal cardio metabolic outcomes } \\
\text { as the Morenga et al. review shows (Barry Popkin) }\end{array}$ \\
\hline
\end{tabular}

Participants $\mathrm{n}=3$ 


\section{A P P E N D I C ES}

\section{Appendix I. MEDLINE search strategy}

1. exp Taxes/

2. exp Government Programs/ec, lj [Economics, Legislation \& Jurisprudence]

3. exp Health Policy/ec, lj [Economics, Legislation \& Jurisprudence]

4. exp Food Dispensers, Automatic/ec, lj, sn [Economics, Legislation \& Jurisprudence, Statistics \& Numerical Data]

5. exp Health Promotion/ec, lj [Economics, Legislation \& Jurisprudence]

6. exp Nutrition Policy/ec, lj [Economics, Legislation \& Jurisprudence]

7. exp Public Health/ec, lj [Economics, Legislation \& Jurisprudence]

8. "demand elasticity".tw.

9. "policy intervention*”.tw.

10. "sales tax".tw.

11. "thin subsidies".tw.

12. "vending machine*”.tw.

13. budget.tw.

14. excise.tw.

15. fiscal.tw.

16. levied.tw.

17. levy.tw.

18. price.tw.

19. priced.tw.

20. prices.tw.

21. pricing.tw.

22. subsidy.tw.

23. subsidies.tw.

24. tax.tw.

25. taxation.tw.

26. taxed.tw.

27. taxes.tw.

28. taxing.tw.

29. OR/1-28

30. exp Dietary Carbohydrates/

31. exp Dietary Sucrose/

32. exp High Fructose Corn Syrup/

33. "chewing gum".tw.

34. "dietary sucrose".tw.

35. (("energy dens*” or "highenergy" or "high energy" or "high-energy" or "low energy" or chips) and (fat* or sugar* or sweet* or food or diet* or nutrition or overweight or drink* or beverage* or protein* or carbohydrate*)).tw.

36. "HED calori*”.tw.

37. "HED-calori*".tw.

38. "highcalori* food"..tw.

39. "high calori* food*”.tw.

40. "high-calori* food"”.tw.

41. "lowcalori* food*".tw.

42. "low calori* food*".tw.

43. "low-calori* food*".tw.

44. "ice cream*".tw.

45. "unhealthy food*”.tw.

46. bakery.tw.

47. biscuit*.tw.

Taxation of sugar-sweetened beverages for reducing their consumption and preventing obesity or other adverse health outcomes 
48. cacao.tw.

49. cake*.tw.

50. calorie*.tw.

51. candy.tw.

52. candies.tw.

53. bonbon*.tw.

54. chocolate*.tw.

55. confectionar*.tw.

56. cookie*.tw.

57. isoglucose.tw.

58. jam.tw.

59. jelly.tw.

60. jellies.tw.

61. liquorice.tw.

62. macronutrient*.tw.

63. maltose.tw.

64. marmalade.tw.

65. marzipan.tw.

66. pastr*.tw.

67. sucrose.tw.

68. sugar.tw.

69. sugars.tw.

70. sugary.tw.

71. sweet*.tw.

72. exp Butter/

73. exp Dietary Fats/

74. exp Energy Intake/

75. exp Fast Foods/

76. exp Margarine/

77. exp Plant Oils/ec [Economics]

78. "fastfood"..tw.

79. "fast food"..tw.

80. "fast-food*".tw.

81. "fattening-food*”.tw.

82. "fattening food"..tw.

83. "fried food"..tw.

84. (coconut OR cooking OR palm OR vegetable OR soya OR soybean OR rapeseed OR linseed OR sunflower OR sesame OR peanut OR groundnut OR copra OR babassu OR olive OR thistle ADJ Oil).tw.

85. "salty-snack*”.tw.

86. “salty snack"”.tw.

87. "snack food*”.tw.

88. "snack-food"”.tw.

89. "takeaway food"”.tw.

90. "takeaway-food*”.tw.

91. "take away food*”.tw.

92. "take away-food*".tw.

93. "take-away food". tw.

94. "take-away-food*”.tw.

95. "whole milk".tw.

96. burger*.tw.

97. butter.tw.

98. cheese.tw.

99. cream.tw.

Taxation of sugar-sweetened beverages for reducing their consumption and preventing obesity or other adverse health outcomes

\section{(Protocol)}

Copyright $\odot 2016$ The Cochrane Collaboration. Published by John Wiley \& Sons, Ltd. 
100. crisps.tw.

101. (egg AND (fat* or sugar* or sweet* or food or diet* or nutrition or overweight or drink* or beverage* or protein* or carbohydrate*)).tw.

102. (eggs AND (fat* or sugar* or sweet* or food or diet* or nutrition or overweight or drink* or beverage* or protein* or carbohydrate*)).tw.

103. (fat AND (Food* or diet $^{*}$ or nutrition or nutrient or eat ${ }^{*}$ or meal ${ }^{*}$ or oil ${ }^{*}$ or carbohydrate* or protein* ${ }^{*}$ or obesity or obese)).tw.

104. (fatty AND (Food* or diet* $^{*}$ or nutrition or nutrient or eat* or meal* or oil* or carbohydrate* or protein* or obesity or obese)).tw.

105. fats.tw.

106. fattening.tw.

107. fries.tw.

108. ghee.tw.

109. lard.tw.

110. margarine.tw.

111. mono-unsat*.tw.

112. monounsat*.tw.

113. omega3.tw.

114. “omega 3".tw.

115. omega-3.tw.

116. pizza.tw.

117. polyunsat*.tw.

118. poly-unsat*.tw.

119. sausage*.tw.

120. suet.tw.

121. exp Carbonated Beverages/

122. exp Food Preferences/

123. exp Food Habits/

124. "caloric-drink".tw.

125. "caloric drink" .tw.

126. "carbonated-beverage*”.tw.

127. "carbonated beverage*”.tw.

128. "carbonated-drink" .tw.

129. “carbonated drink"”.tw.

130. “energy-drink" .tw.

131. "energy drink*”.tw.

132. "fizzy-drink*”.tw.

133. “fizzy drink*”.tw.

134. "high-calori* drink*”.tw.

135. "high calori* drink*".tw.

136. "soda pop”.tw.

137. "soft-drink"..tw.

138. "soft drink*".tw.

139. “sport-drink*”.tw.

140. “sport* drink" ${ }^{*}$.tw.

141. "sport*-drink"..tw.

142. cola.tw.

143. soda.tw.

144. SSB*.tw.

145. syrup*.tw.

146. OR/30-145

147. 29 AND 146

148. (animals NOT (humans AND animals)).sh.

149. 147 NOT 148

Taxation of sugar-sweetened beverages for reducing their consumption and preventing obesity or other adverse health outcomes 


\section{CONTRIBUTIONS OFAUTHORS}

Thomas L. Heise: protocol draft, contributed to all stages of the protocol development

Srinivasa Vittal Katikireddi: reviewed and contributed to the development of the draft protocol and search strategy

Frank Pega: reviewed and contributed to the development of the draft protocol and search strategy

Gerald Gartlehner: reviewed and contributed to the development of the draft protocol

Candida Fenton: search strategy development

Ursula Griebler: reviewed the draft protocol

Isolde Sommer: reviewed the draft protocol

Manuela Pfinder: protocol draft, contributed to all stages of the protocol development

Stefan K. Lhachimi: conceived and initiated the review and contributed to all stages of the protocol development

\section{DECLARATIONSOF INTEREST}

Thomas Heise: none declared

Srinivasa Vittal Katikireddi is a member of the steering group of Obesity Action Scotland, to whom he provides unpaid advice on the evidence base for public health actions to tackle obesity

Frank Pega is a Technical Officer at the World Health Organization

Gerald Gartlehner: none declared

Candida Fenton: none declared

Ursula Griebler: none declared

Isolde Sommer: none declared

Manuela Pfinder: none declared

Stefan K. Lhachimi received reimbursement for travel costs for participating in May 2013 in a workshop organised by the University of Maastricht at Schiphol (Netherlands) which was funded unrestrictedly by Nutricia Advanced Medical Nutrition (NAMN).

\section{SOURCES OF SUPPORT}

\section{Internal sources}

- Institute for Public Health and Nursing Research, Health Sciences Bremen, University of Bremen, Bremen, Germany. The lead reviewer is employed by the University of Bremen. Co-authors are working at the corresponding institutions.

- UK Medical Research Council, Other. Srinivasa Vittal Katikireddi is funded by a NRS Senior Clinical Fellowship (SCAF/15/02), the UK Medical Research Council (MC'UU'12017/15) and the Chief Scientist's Office (SPHSU15) 


\section{External sources}

- No sources of support supplied

\section{(Protocol)}

Copyright $\odot 2016$ The Cochrane Collaboration. Published by John Wiley \& Sons, Ltd. 